\title{
Gold(I) Complexes with P-Donor Ligands and Their Biological Evaluation
}

\author{
Monika Richert ${ }^{1, *} \mathbb{\infty}$, Renata Mikstacka ${ }^{1} \mathbb{1}$, Mariusz Walczyk ${ }^{2}$, Marcin Janusz Cieślak ${ }^{3}{ }^{\mathbb{D}}$, \\ Julia Kaźmierczak-Barańska ${ }^{3}$, Karolina Królewska-Golińska ${ }^{3}$, Tadeusz Mikołaj Muzioł ${ }^{2}$ iD and Stanisław Biniak ${ }^{2}$ \\ 1 Faculty of Pharmacy, Collegium Medicum in Bydgoszcz, Nicolaus Copernicus University in Toruń, Jurasza 2, \\ 85-094 Bydgoszcz, Poland; mikstar@cm.umk.pl \\ 2 Faculty of Chemistry, Nicolaus Copernicus University in Toruń, Gagarina 7, 87-100 Toruń, Poland; \\ mwalczyk@umk.pl (M.W.); tmuziol@chem.umk.pl (T.M.M.); sbiniak@umk.pl (S.B.) \\ 3 Centre of Molecular and Macromolecular Studies, Polish Academy of Sciences, Sienkiewicza 112, 90-363 Lódź, \\ Poland; marcin@cbmm.lodz.pl (M.J.C.); julia@cbmm.lodz.pl (J.K.-B.); kkrolews@cbmm.lodz.pl (K.K.-G.) \\ * Correspondence: monika.richert@cm.umk.pl; Tel.: +48-52-585-38-03; Fax: +48-52-585-38-04
}

Citation: Richert, M.; Mikstacka, R.; Walczyk, M.; Cieślak, M.J.;

Kaźmierczak-Barańska, J.;

Królewska-Golińska, K.; Muzioł, T.M.; Biniak, S. Gold(I) Complexes with P-Donor Ligands and Their Biological Evaluation. Processes 2021, 9, 2100. https://doi.org/10.3390/pr9122100

Academic Editor: Carla Vitorino

Received: 12 October 2021

Accepted: 19 November 2021

Published: 23 November 2021

Publisher's Note: MDPI stays neutral with regard to jurisdictional claims in published maps and institutional affiliations.

Copyright: (c) 2021 by the authors. Licensee MDPI, Basel, Switzerland. This article is an open access article distributed under the terms and conditions of the Creative Commons Attribution (CC BY) license (https:/ / creativecommons.org/licenses/by/ $4.0 /)$.

\begin{abstract}
Gold(I) complexes with phosphine ligands-[Au(TrippyPhos)Cl] (1) (TrippyPhos = 1-[2[bis(tert-butyl)phosphino]phenyl]-3,5-diphenyl-1H-pyrazole), [Au(BippyPhos) $\mathrm{Cl}] \cdot 0.5 \mathrm{CH}_{2} \mathrm{Cl}_{2}$ (2) (BippyPhos = 5-(di-tert-butylphosphino)-1' $, 3^{\prime}, 5^{\prime}$-triphenyl-1'H-[1,4']bipyrazole), and [Au(meCgPPh)Cl] (3) (meCgPPh =1,3,5,7-tetramethyl-6-phenyl-2,4,8-trioxa-6-phosphaadamantane-were investigated as types of bioactive gold metallodrugs. Complexes (1)-(3) were characterized using $\mathrm{IR},{ }^{1} \mathrm{H},{ }^{13} \mathrm{C},{ }^{31} \mathrm{P}$ NMR spectroscopy, elemental analysis and mass spectrometry (FAB-MS). Complexes of (1) and (2) exhibited substantial in vitro cytotoxicity $\left(\mathrm{IC}_{50}=0.5-7.0 \mu \mathrm{M}\right)$ against both the cisplatin-sensitive and -resistant variants of the A2780 human ovarian carcinoma cell line, as well as against the A549 human lung carcinoma, K562 chronic myelogenous leukemia, and HeLa (human cervix carcinoma) cells. However, among the compounds studied, complex (2) showed the most promising biological properties: the highest stability in biologically relevant media, selectivity towards cancer cells over the non-cancer cells (HUVEC, human umbilical vein endothelial cells), and the highest inhibitory effect on cytosolic NADPH-dependent reductases in A2780 and A2780cis cells among the gold complexes under analysis.
\end{abstract}

Keywords: gold(I) phosphines complex; anticancer drug; cytotoxic effect; NADPH activity

\section{Introduction}

For several decades now, gold(I) complexes have attracted attention as potential metallodrugs due to their activities targeting pathways involved in cancer development and progression. A lead compound among $\mathrm{Au}(\mathrm{I})$ complexes-auranofin [2,3,4,6-tetra-oacetyl-1-thio- $\beta$-D-glucopyranosato-S-(triethyl-phosphine) gold] - is a thiol-reactive gold(I)containing compound approved by FDA as an anti-arthritic drug. Most recently, its anti-tumor effect against cancer in vitro and in vivo models has been recognized. Auranofin inhibited the proliferation and survival of the p53-null ovarian carcinoma SKOV3 cell line [1] suggesting a p53-independent mechanism of auranofin-induced apoptosis. Auranofin was effective as a cytotoxic agent in cisplatin-resistant human ovarian cancer cells $\mathrm{C} 13^{*}$; the anti-proliferative effect of auranofin was accompanied by the inhibition of thioredoxin reductase activity in the cancer cells studied [2]. Since the 1990s, the thioredoxin reductase system has been identified as the primary target of auranofin activity [3].

NADPH-dependent reductases - thioredoxin (Trx) and glutathione systems - are the two most important electron-donor cellular components protecting cells against oxidative stress. The Trx system comprises thioredoxin, thioredoxin reductase ( $\operatorname{Tr} x \mathrm{R})$ and the coenzyme NADPH. Thioredoxin reductase is a selenocysteine-dependent enzyme responsible for anti-oxidant defense, which maintains the cellular redox homeostasis. It plays a crucial 
role in redox-dependent signaling pathways, inhibits apoptosis and controls cell growth and survival. Two forms of mammalian TrxRs-TrxR1 and TrxR2-similar in structure and activity, are identified, which are located in the cytoplasm and mitochondria, respectively [4]. The function of TrxR1 is to retain cytosolic thioredoxin (Trx1) in the reduced state using NADPH as an electron donor. TrxR1 is involved in the proliferation, apoptosis and metastasis of tumor cells. In many human tumors, $\operatorname{TrxR} 1$ is overexpressed, and a higher level of this enzyme was indeed shown [5,6]. For several decades, the Trx system has been considered a promising target of anti-cancer therapeutic agents. The inhibition of TrxR activity by binding specific inhibitors to the selenocysteine-cysteine redox pair in the C-terminal active site of the enzyme increases the level of the oxidized form of thioredoxin. In the tumor cells that exhibit a high level of $\operatorname{TrxR}$, this may inhibit cell growth and the activation of pathways leading to apoptosis. An increased interest in the search for efficient TrxR inhibitors with cytotoxic activity towards cancer cells resulted in identifying many groups of active compounds [6,7] interacting with Trx and TrxR directly or influencing their expression. Compounds targeting the Trx system are considered to have therapeutic potential for cancer treatment [8]. Some TrxR inhibitors have been tested in clinical trials. One of them is arsenic trioxide (ATO), approved by the FDA for use in cancer therapy for acute promyelocytic leukemia and solid tumors [9]. 1-Methyl-propyl-2-imidazolyl disulfide (PX-12) has completed a phase I trial and is now in phase II to treat pancreatic cancer [10]. Suberoylanilide hydroxamic, acid (SAHA), known as a histone deacetylase inhibitor, is a therapeutic agent for the treatment of cutaneous T-cell lymphoma which also indirectly targets the Trx system by upregulating endogenous Trx inhibitor TBP-2 [11]. The complexes of N-heterocyclic carbene (NHC) with gold(I) were identified as TrxR inhibitors with strong anti-tumor properties. The selected NHC gold complexes revealed strong effects on cellular metabolism, apoptosis induction and cytotoxic activity against daunorubicine-resistant cell line [12].

Taking into account the instability of auranofin and the side effects which it causes, a search for other efficient TrxR inhibitors among gold complexes has been initiated [13]. Auranofin derivatives were designed, and synthesized, and their cytotoxicity towards cancer cells was investigated [12,14-16]. A way to improve the properties of gold(I) phosphine complexes is to choose a suitable ligand that relevantly could influence lipophilicity, physiological stability, and selective cytotoxicity in cancer cells over normal cells $[17,18]$. Maintenance of the hydrophilic-lipophilic properties of a therapeutic agent in balance is crucial for its specificity against tumor cells, because highly lipophilic gold(I) complexes exert severe toxicity to healthy normal tissues.

There is a great interest in the anti-cancer activity of gold(I) phosphine complexes owing to their wide spectrum of anti-cancer properties [19-21]. N-heterocyclic phosphines represent an interesting group within the large family of phosphine ligands owing to their intrinsic properties and considerable structural diversity [22]. Gold(I) phosphine complexes selectively inhibited cytosolic and mitochondrial thioredoxin reductase without affecting glutathione reductase and glutathione peroxidase [15]. N,P-hybrid compounds as ligands with potential hemilabile properties [23] seem to improve the pharmacokinetic properties of gold(I) [24]. The application of 1,3,5-triaza-7-phosphaadamantane (PTA) as a ligand in the ruthenium-arene-PTA (RAPTA) class of compounds proved a great success for several compounds in this group, which appeared at the preclinical development stage to be potential anti-metastatic agents [25]. Moreover, some other metal complexes, such as platinum, osmium rhodium, iridium, and gold with PTA or its derivatives, have displayed a promising anti-cancer activity against primary and metastatic tumors [26-28].

In the present study, the gold(I) complexes (Figure 1) with N-pyrazole, P-phosphine hybrids ligands (TrippyPhos, BippyPhos), and the derivative of 1,3,5-triaza-7-phosphaadamantane (meCgPPh) were synthesized, and their cytotoxic activity against cancer cells was evaluated. Compound [Au(TrippyPhos)Cl] (1) is a novel $\mathrm{Au}(\mathrm{I})$ complex, whereas the structures of [Au(BippyPhos)Cl] $0.5 \mathrm{CH}_{2} \mathrm{Cl}_{2}(2)$ as $[\mathrm{Au}(\mathrm{BippyPhos}) \mathrm{Cl}]$ and $[\mathrm{Au}(\mathrm{meCgPPh}) \mathrm{Cl}](3)$ have been described earlier $[29,30]$. Compound (2) has been tested as a potential precatalyst of 
the hydrohydrazination of terminal aryl alkynes [29]. The complexes (1), (2), and (3) were characterized using IR, ${ }^{1} \mathrm{H},{ }^{13} \mathrm{C},{ }^{31} \mathrm{P}$ NMR spectroscopy, elemental analysis and mass spectrometry (FAB-MS). Additionally, the X-ray data which were determined confirmed the structure of (2) and (3) complexes. These results were discussed with regard to the earlier structure description.

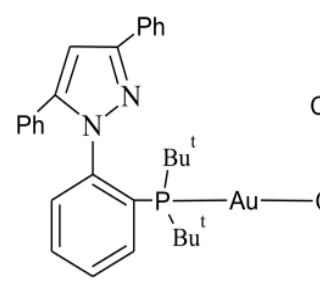

(1)<smiles>Cl[14C](Cl)(Br)c1ccnn1-c1c(-c2ccccc2)nn(-c2ccccc2)c1-c1ccccc1</smiles>

(2)<smiles>CC12CC3(Cl)OC(C)(CC(C)(O1)P3c1ccccc1)O2</smiles>

(3)

Figure 1. The schematic representation of compounds studied.

The panel of selected cancer cell lines used in the biological studies included: human ovarian carcinoma cell line A2780, cisplatin resistant cell line A2780cis, human lung carcinoma A549, chronic myelogenous leukemia K562, human cervix carcinoma HeLa cells and normal HUVEC human umbilical vein endothelial cells. The stability of the compounds under study in PBS and a cell culture medium containing fetal calf serum (FCS) of complexes was determined. The values of $\log P$ coefficients were calculated to estimate the effect of lipophilic properties on the cytotoxic activity of the compounds examined. Moreover, the inhibition of the activity of NADPH-dependent reductases in the cytosol of both A2780 and A2780cis cells was also determined.

\section{Materials and Methods}

\subsection{Materials}

$\mathrm{HAuCl}_{4} \cdot 3 \mathrm{H}_{2} \mathrm{O}, 1$-[2-[bis(tert-butyl)phosphino]phenyl]-3,5-diphenyl-1H-pyrazole (TrippyPhos), 5-(di-tert-butylphosphino)-1 $1^{\prime}, 3^{\prime}, 5^{\prime}$-triphenyl- ${ }^{\prime} H$-[1, $\left.4^{\prime}\right]$ bipyrazole (BippyPhos), 1,3,5,7-tetramethyl-6-phenyl-2,4,8-trioxa-6-phosphaadamantane (meCgPPh), auranofin, cisplatin, a Thioredoxin Reductase Assay Kit, CelLytic Extraction Reagent, and Protease Inhibitor Cocktail were provided by Sigma-Aldrich (St. Louis, MI, USA), and used as supplied. RPMI 1640, fetal calf serum (FCS), antibiotics/antimycotics, trypsin and phosphatebuffered saline (PBS) were obtained from Cytogen.

\subsection{Cell Lines and Culture Conditions}

The human cisplatin-sensitive ovarian cancer cell line A2780 was a gift from Prof. Hanna Piotrowska-Kempisty (Department of Toxicology, Poznań University of Medical Sciences, Poland). The cisplatin-resistant cell line A2780cis was obtained from SigmaAldrich (USA). HeLa, K562, and A549 cells were purchased from the European Collection of Authenticated Cell Cultures (ECACC) operated by Public Health England, and cell line MDA-MB-231 was purchased from the Department of Genotherapy, Collegium Medicum, UMK in Toruń. Human umbilical vein endothelial cells (HUVEC) were obtained from Life Technologies. Cell lines were cultured in RPMI-1640 medium supplemented with 10\% FCS and antibiotics/antimycotics (penicillin $100 \mathrm{U} / \mathrm{mL}$; streptomycin $100 \mu \mathrm{g} / \mathrm{mL}$ ) at $37{ }^{\circ} \mathrm{C}$ in a $5 \% \mathrm{CO}_{2}$ humidified atmosphere and subcultured twice a week. $7 \times 10^{3}$ cells (HeLa, K562, A549) or $20 \times 10^{3}$ (MDA-MB-231, A2780 and A2780cis), and $10 \times 10^{3}$ cells (HUVEC) were seeded on each well on a 96-well plate.

\subsection{Synthesis of Complexes (1)-(3)}

$\mathrm{HAuCl}_{4} \cdot 3 \mathrm{H}_{2} \mathrm{O}(100 \mathrm{mg}, 0.25 \mathrm{mmol})$ was dissolved in $\mathrm{EtOH}(10 \mathrm{~mL})$ and cooled to $5{ }^{\circ} \mathrm{C}$ in ice bath, then the synthesis was carried out according to the literature [31]. We added $0.50 \mathrm{mmol}$ of the corresponding phosphine dissolved in dichloromethane to the mixture 
and it was stirred for about $30 \mathrm{~min}$, at which time the yellow solution became colorless. The solution was set to slow evaporation. Complexes (1)-(3) were received after 3 days as a white solid of (1) and colorless crystals of (2) and (3).

\subsection{1. [Au(TrippyPhos)Cl] (1)}

Yield: 93\%. Analysis for $\mathrm{AuC}_{29} \mathrm{H}_{33} \mathrm{~N}_{2} \mathrm{PCl}$. Calculated (\%): C, 55.42; $\mathrm{H}, 5.25 ; \mathrm{N}, 4.46$. Found (\%): C, 55.55; H, 5.36; N, 4.36. FAB-MS: $m / z=673.0\left[\mathrm{M}^{+}\right], 637.0\left[\mathrm{Au}(\text { TrippyPhos) }]^{+}\right.$,

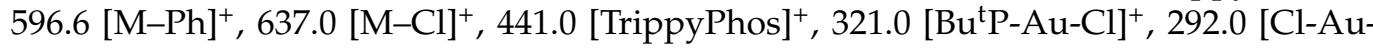
$\left.\mathrm{PH}\left(\mathrm{CH}_{2} \mathrm{CH}_{3}\right)\right]^{+}, 232.1[\mathrm{Au}-\mathrm{ClH}]^{+}, 207.0\left[\mathrm{PhCH}=\mathrm{N}_{2} \mathrm{H}_{2}(\mathrm{Ph})\right]^{+}, 147.0\left[\mathrm{H}_{2} \mathrm{P}\left(\mathrm{Bu}^{\mathrm{t}}\right)_{2}\right]^{+}, 136.0$ $\left[\mathrm{Ph}-\mathrm{PCH}=\mathrm{CH}_{3}\right]^{+}$. IR KBr pellet, $\mathrm{cm}^{-1}$ : 1598,1588 $\vee(\mathrm{C}=\mathrm{N}) ; 1483,1461 \vee(\mathrm{C}-\mathrm{N}) ; 1167 v(\mathrm{~N}-\mathrm{N})$; 1443, 1077, 1025, 969, 764, 692, 594, 538 v(P-C); 1485, 1462, $1440 \vee(\mathrm{C}-\mathrm{C})(\mathrm{Ph}) ; 1543 \vee(\mathrm{C}=\mathrm{C})$ (Ph); 3040, $3058 v(\mathrm{C}-\mathrm{H})(\mathrm{Ph}) ; 2965,2901,2869,1364 v(\mathrm{C}-\mathrm{H})$ (aliphatic); 1209, $1125(\delta(\mathrm{C}-\mathrm{H})$, and $v(\mathrm{C}-\mathrm{C}))$; 446, $425 v(\mathrm{Au}-\mathrm{P}) .{ }^{1} \mathrm{H}$ NMR $\left(400.1 \mathrm{MHz}, \mathrm{CDCl}_{3}\right): \delta 8.04-7.98$ (m, 2H, Ph-Pyr), 7.91-7.89 (m, 2H, Pyr-Ph), 7.86-7.84 (m, 1H, N-Ph-P), 7.46-7.19 (m, 3H, Pyr-Ph; 3H, Ph-Pyr; 3H, P-Ph, ), 7.03 (1H, Pyr), 1.37 (d, J = 16.0 Hz, 9H, tBu), 1.13 (d, J = 15.6 Hz, 9H, tBu); ${ }^{13} \mathrm{C}$ NMR (100.6 MHz, $\left.\mathrm{CDCl}_{3}\right): \delta$ 150.7, 150.1 (1C, (Ph)C-C(Pyr)), 146.9, $146.8(1 \mathrm{C}$, (Pyr)C-C(Ph)), 142.2 (1C, (Pyr)N-C(Ph)), 133.4, 133.5 (1C, (Ph)C-C(Pyr)), 133.2 (d, J = $8 \mathrm{~Hz}$ 1C, Ph-P), 133.1 (d, J = 8 Hz 1C, (Ph)C-P), 131.1 (1C, (Pyr)C-C(Ph)), 129.9 (1C, Ph-Pyr, 1C, Pyr-Ph), 129.6 (2C, Ph-Pyr, 2C, Pyr-Ph), 129.5 (2C, Pyr-Ph), 129.4 (1C, Ph-P), 129.0 (1C, Ph-P), 127.4 (2C, Ph-Pyr), 107.8 (1C, Ph-P), 104.7 (H-C(Pyr)), 39.3 (d, J = 44 Hz C, tBu)), 39.1 (d, $J=44 \mathrm{~Hz} \mathrm{C},(t \mathrm{Bu})), 32.2\left(\mathrm{~d}, J=28 \mathrm{~Hz}_{3} \mathrm{CH}_{3},(t \mathrm{Bu})\right) ; 31.6\left(\mathrm{~d}, J=24 \mathrm{~Hz} 3 \mathrm{CH}_{3},(t \mathrm{Bu})\right)$; ${ }^{31} \mathrm{P}$ NMR $\left(162.0 \mathrm{MHz}, \mathrm{CDCl}_{3}\right): \delta 57.6$.

\subsection{2. [Au(BippyPhos) $\mathrm{Cl}] \cdot 0.5 \mathrm{CH}_{2} \mathrm{Cl}_{2}$ (2)}

Yield: $88 \%$. Analysis for $\mathrm{AuC}_{32.5} \mathrm{H}_{36} \mathrm{~N}_{4} \mathrm{PCl}_{2}$. Calculated (\%): C, 49.90; H, 4.61; N, 7.16. Found (\%): C, 50.05; H, 4.79; N, 7.38; FAB-MS: $m / z=739.3$ [Au(BippyPhos)Cl] $]^{+}, 703.3$ [Au(BippyPhos)] $^{+}, 506.1$ [BippyPhos] $^{+}$. IR KBr pellet, $\mathrm{cm}^{-1}: 1596$ v(C=N), (pyr); 1496, 1471 $v(\mathrm{C}-\mathrm{N}), 1164,1158$ v(N-N); 1453, 1072, 1059, 964, 764, 698, 527 v(P-C); 1453 v(C-C) (Ph); $1560 \vee(\mathrm{C}=\mathrm{C})(\mathrm{Ph}) ; 3064 \vee(\mathrm{C}-\mathrm{H})(\mathrm{Ph}) ; 2965,2956,2902,1380 \vee(\mathrm{C}-\mathrm{H})$ (aliphatic); $1188(\delta(\mathrm{C}-\mathrm{H})$, and $v(\mathrm{C}-\mathrm{C})) ; 471 v(\mathrm{Au}-\mathrm{P}) .{ }^{1} \mathrm{H}$ NMR $\left(400.1 \mathrm{MHz}, \mathrm{CDCl}_{3}\right): \delta 8.11(\mathrm{~d}, J=2.0 \mathrm{~Hz}, 1 \mathrm{H}, \mathrm{Pyr})$, 7.73-7.72 (m, 2H, Ph), 7.54-7.52 (m, 2H, Ph), 7.48-7.45 (m, 3H, Ph), 7.34-7.26 (m, 4H, $\mathrm{Ph}), 7.22-7.14(\mathrm{~m}, 4 \mathrm{H}, \mathrm{Ph}), 6.79$ (d, $J=2.4 \mathrm{~Hz}, 1 \mathrm{H}, \mathrm{Pyr}), 0.81(\mathrm{~d}, J=14.4 \mathrm{~Hz}, 9 \mathrm{H}, t \mathrm{Bu}), 0.78$ $(\mathrm{d}, \mathrm{J}=14.4 \mathrm{~Hz}, 9 \mathrm{H}, t \mathrm{Bu}) ; 5.48\left(\mathrm{~s}, 2 \mathrm{H}, \mathrm{CH}_{2} \mathrm{Cl}_{2}\right) .{ }^{13} \mathrm{C} \mathrm{NMR}\left(100.6 \mathrm{MHz}, \mathrm{CDCl}_{3}\right)$ : $\delta 150.6(1 \mathrm{C}$, (Pyr)C-C(Ph)), 142.3 (1C, HC(Pyr)-P(tBu)), 141.5 (1C, (Pyr)C-N(Pyr)), 140.7 (1C, (Pyr)C$\mathrm{C}(\mathrm{Ph})), 133.4-127.0$ (18C, 3Ph-Pyr), 122.8 (1C, HC(Pyr)-P(tBu)), 115.9 (d, J = 28 Hz, 1C, $(\mathrm{Pyr}) \mathrm{C}-\mathrm{P}(\mathrm{Bu})), 30.7(\mathrm{~d}, J=28 \mathrm{~Hz}, 1 \mathrm{C},(t \mathrm{Bu})), 30.4(\mathrm{~d}, J=28 \mathrm{~Hz}, 1 \mathrm{C},(t \mathrm{Bu})), 30.8(\mathrm{~d}, J=28 \mathrm{~Hz}$ $\left.3 \mathrm{CH}_{3},(t \mathrm{Bu})\right), 30.4\left(\mathrm{~d}, \mathrm{~J}=24 \mathrm{~Hz} 3 \mathrm{CH}_{3},(t \mathrm{Bu})\right) ; 59.7\left(\mathrm{CH}_{2} \mathrm{Cl}_{2}\right) .{ }^{31} \mathrm{P} \mathrm{NMR}\left(162.0 \mathrm{MHz}, \mathrm{CDCl}_{3}\right)$ : $\delta 51.3$.

\subsection{3. $[\mathrm{Au}(\mathrm{meCgPPh}) \mathrm{Cl}](3)$}

Yield: 95\%. Analysis for $\mathrm{AuC}_{16} \mathrm{H}_{21} \mathrm{O}_{3} \mathrm{PCl}$. Calculated (\%): C, 36.68; H, 4.01. Found (\%): C, 36.79; H, 4.16. FAB-MS: $m / z=524.4\left[\mathrm{M}^{+}\right], 488.9[\mathrm{Au}(\mathrm{meCgPPh})]^{+}, 292.3[\mathrm{meCgPPh}]^{+}$, 232.1 [Au-ClH] $^{+}$. IR KBr pellet, $\mathrm{cm}^{-1}:$ 1468, 1087, 979, 891, 757, 699, 582 v(P-C); 1436 $v(\mathrm{C}-\mathrm{C})(\mathrm{Ph}) ; 2992,2988 ; v(\mathrm{C}-\mathrm{H})(\mathrm{Ph}) ; 2966,2929,1380,1343$ v(C-H)(aliphatic); 1265, 1135 $(\delta(\mathrm{C}-\mathrm{H})$, and $v(\mathrm{C}-\mathrm{C})) ; 470,420 v(\mathrm{Au}-\mathrm{P}) .{ }^{1} \mathrm{H}$ NMR $\left(400.1 \mathrm{MHz}, \mathrm{CDCl}_{3}\right): \delta 1.26\left(\mathrm{~s}, 3 \mathrm{H}, \mathrm{CH}_{3}\right)$, 1.25 (s, 3H, CH $\left.\mathrm{CH}_{3}\right), 1.51\left(\mathrm{~s}, 3 \mathrm{H}, \mathrm{CH}_{3}\right), 1.53\left(\mathrm{~s}, 3 \mathrm{H}, \mathrm{CH}_{3}\right), 2.09\left(\mathrm{~d}, J=14 \mathrm{~Hz}, 1 \mathrm{H}, \mathrm{CH}_{2}\right), 2.07$ (d, $\left.J=14 \mathrm{~Hz}, 1 \mathrm{H}, \mathrm{CH}_{2}\right), 1.96\left(\mathrm{~d}, J=14 \mathrm{~Hz}, 1 \mathrm{H}, \mathrm{CH}_{2}\right), 1.92\left(\mathrm{~d}, J=14 \mathrm{~Hz}, 1 \mathrm{H}, \mathrm{CH}_{2}\right), 7.85-7.82$ (m, 2H, Ph), 7.40-7.35 (m, 3H, Ph). $\left.{ }^{13} \mathrm{C} \mathrm{NMR} \mathrm{(100.6} \mathrm{MHz,} \mathrm{CDCl}_{3}\right): \delta 136.6(\mathrm{~d}, \mathrm{~J}=48 \mathrm{~Hz}, 2 \mathrm{C}$, $\mathrm{Ph}), 133.8$ (d, $J=12 \mathrm{~Hz}, 1 \mathrm{C}, \mathrm{Ph}), 130.3$ (d, $J=40 \mathrm{~Hz}, 2 \mathrm{C}, \mathrm{Ph}), 125.8,125.4$ (2s, 1C, Ph), 97.5 $\left.\left(\mathrm{d}, 2 \mathrm{C}, \mathrm{J}=5.2 \mathrm{~Hz}\left(\mathrm{CH}_{3}\right)\left(\mathrm{CH}_{2}\right) \mathrm{CO}_{2}\right), 75.5,75.2\left(2 \mathrm{~s}, 1 \mathrm{C},\left(\mathrm{CH}_{3}\right)\left(\mathrm{CH}_{2}\right) \mathrm{CO}_{2}\right)\right), 74.5,74.1(2 \mathrm{~s}, 1 \mathrm{C}$, $\left.\left.\left(\mathrm{CH}_{3}\right)\left(\mathrm{CH}_{2}\right) \mathrm{CO}_{2}\right)\right), 45.6$, (d, J = $\left.40 \mathrm{~Hz}, 1 \mathrm{C}, \mathrm{CH}_{2}\right), 38.0\left(\mathrm{~d}, 1 \mathrm{C}, \mathrm{J}=8.4 \mathrm{~Hz}, 1 \mathrm{C}, \mathrm{CH}_{2}\right), 28.7,28.4$ $\left(2 \mathrm{~s}, 2 \mathrm{C}, 2 \mathrm{CH}_{3}\right), 27.5,27.4,\left(2 \mathrm{~s}, 1 \mathrm{C}, \mathrm{CH}_{3}\right), 26.5,26.4\left(2 \mathrm{~s}, 2 \mathrm{C}, 2 \mathrm{CH}_{3}\right) .{ }^{31} \mathrm{P} \mathrm{NMR}(162.0 \mathrm{MHz}$, $\left.\mathrm{CDCl}_{3}\right): \delta 26.2$. 


\subsection{Experimental Methods}

\subsubsection{Nuclear Magnetic Resonance (NMR) Spectroscopy}

The NMR spectra were recorded at RT in $\mathrm{CDCl}_{3}$ solutions with a Bruker Avance III $400 \mathrm{MHz}$ spectrometer operated at $400.0,100.6$, and $162.0 \mathrm{MHz}$ for ${ }^{1} \mathrm{H},{ }^{13} \mathrm{C},{ }^{31} \mathrm{P}$, respectively. Chemical shifts are referenced to external TMS $\left({ }^{1} \mathrm{H},{ }^{13} \mathrm{C}\right)$ or $85 \% \mathrm{H}_{3} \mathrm{PO}_{4}\left({ }^{31} \mathrm{P}\right)$.

\subsubsection{Fast Atom Bombardment Mass Spectrometry (FAB-MS)}

The FAB-MS data were determined on Finnigan MAT 95 mass spectrometer (NBA, $\mathrm{Cs}^{+}$gun operating at $13 \mathrm{keV}$ ).

\subsubsection{Elemental Analyses}

Elemental analyses for the obtained complexes were performed on a Vario EL of Elementar Analysensysteme GmbH.

\subsubsection{X-ray Diffraction Data}

Diffraction data for (2) and (3) were collected on Oxford Sapphire with a CCD area detector at room temperature and were reduced using CrysAlis Pro [32]. For (2) twinning was detected and hence, this process was finalized in monoclinic $\mathrm{P} 2{ }_{1}$ space group with two domains related by a two-fold axis. The numerical absorption correction (RED171 package of programs, Oxford Diffraction, 2000) was applied for both complexes. Both structures were solved by direct methods and refined by full-matrix least-squares techniques on $\mathrm{F}^{2}$ with SHELXL program and for the twinned data set of (2) HKLF 5 flag was used for the refinement $[33,34]$. Anisotropic thermal displacement parameters were applied for heavy atoms, whereas hydrogen atoms attached to carbon atoms were located at calculated positions and refined with isotropic thermal displacement parameters fixed to a value of $20 \%$ or $50 \%$ higher than those of the corresponding carbon atoms. For (2), ISOR restraints were applied for several atoms mainly from water molecules or tert-butyl groups and FLAT restraint was used for C21 phenyl ring to assure stable refinement and geometry. All figures were prepared in DIAMOND and ORTEP-3 [35,36]. The results of data collections and refinement have been summarized in Table S1 (Supplementary Materials). CCDC 2049170 and 2049171 contain the supplementary crystallographic data for (2) and (3). These data can be obtained free of charge from the Cambridge Crystallographic Data Centre via www.ccdc.cam.ac.uk (accessed on 1 October 2021).

\subsubsection{Lipophilicity and Solution Stability}

The lipophilicity of complexes (1), (2) and (3) was determined according to the previous procedure published in the paper [37]. The $\log P$ values and the solution stability of gold(I) complexes were characterized using SHIMADZU UV-1800 UV-Vis spectrophotometer in the range $200-700 \mathrm{~nm}$. The stability of complexes was determined in phosphatebuffered saline (PBS) and in a cell culture medium with $10 \%$ FCS.

Stock solutions $(1 \mathrm{mM})$ of complexes (1)-(3) were prepared in DMSO. For the studies of stability, the gold(I) complexes solutions were diluted with PBS or medium (in which cell lines were cultured) to achieve a final gold concentration of $50 \mu \mathrm{M}$. Background scans were performed with the corresponding PBS or cell culture medium.

\subsubsection{MTT Cell Viability Assay}

A $100 \mu \mathrm{L}$ aliquot of cells $\left(20 \times 10^{3}\right.$ cells/well) was added to each well of a 96-well plate and incubated at $37^{\circ} \mathrm{C}$ in a humidified incubator. After $24 \mathrm{~h}$ incubation, the studied compounds at concentrations that ranged between $1 \mu \mathrm{M}$ and $100 \mu \mathrm{M}$ (MDA-MB-231, A2780 and A2780cis) or $0.1 \mu \mathrm{M}$ and $200 \mu \mathrm{M}$ (HeLa, K562, A549) were added in $100 \mu \mathrm{L}$ medium solution to the cells. According to the manufacturer's instructions, human umbilical vein endothelial cells (HUVEC) were cultured in Medium 200 with low serum growth supplement (Life Technologies). $10 \times 10^{3}$ cells were seeded on each well on a 96-well plate (Nunc). 
Control cultures were treated with DMSO as a vehicle $(0.5 \% v / v)$. After incubation the cells were rinsed with PBS and $180 \mu \mathrm{L}$ of MTT $(0.5 \mathrm{mg} / \mathrm{mL})$ dissolved in PBS was added to each well. Cells with MTT were incubated for $2 \mathrm{~h}$. Then the solution was removed, and formazan crystals were dissolved in $200 \mu \mathrm{L}$ of DMSO (MDA-MB-231, A2780 and A2780cis) or 20\% SDS and 50\% DMF at pH 4.7 (HeLa, K562, A549) with shaking carefully for $5 \mathrm{~min}$. The absorbance at $570 \mathrm{~nm}$ and $650 \mathrm{~nm}$ was measured using a microplate reader. The viability was expressed as the percent of the control value. The values of $\mathrm{IC}_{50}$ (the concentration of test compound required to reduce the cell survival fraction to $50 \%$ of the control) were calculated from dose-response curves. Statistical data analysis was performed with Student's t-test.

\subsubsection{Thioredoxin Reductase Activity Assay}

Cells were harvested, counted and washed with PBS. Then they were lysed with CelLytic Extraction Reagent containing 1\% of a protease inhibitor cocktail. After 15 min of incubation with shaking, lysates were centrifuged at $12,000 \times g$ for $15 \mathrm{~min}$ at $4{ }^{\circ} \mathrm{C}$, and the obtained supernatants were transferred to chilled test tubes and kept in ice. The activity of NADPH-dependent reductases was determined according to the manufacturer's instruction. Thioredoxin reductase activity was calculated as a difference between the activity of NADPH-dependent reductases and residual activity obtained using a specific TrxR inhibitor. The samples of cytosol were added to the working buffer; $100 \mathrm{mM}$ potassium phosphate with $10 \mathrm{mM}$ EDTA and 0.24 mM NADPH. 5,5'-Dithiobis(2-nitrobenzoic) acid at a concentration of $3 \mathrm{mM}$ was used as a substrate. The assay was performed at room temperature $\left(25^{\circ} \mathrm{C}\right)$. Enzyme activity was determined spectrophotometrically by measuring the absorbance at $412 \mathrm{~nm}$ and expressed in units ( 1 unit equal to the absorbance of 0.1 per $10^{8}$ cells). The measurements were made using a SHIMADZU UV-1800 UV-Vis spectrophotometer. Results were the means of three independent experiments. The test compounds dissolved in DMSO were added at the final concentration of $10 \mu \mathrm{M}$. The amount of DMSO in the reaction mixture did not exceed $0.5 \%$. Statistical data analysis was performed with Student's $t$-test.

\section{Results and Discussion}

\subsection{Synthesis and Characterization}

Phosphine-gold(I) complexes were synthesized by the reaction of of $\left[\mathrm{HAuCl}_{4} \cdot \mathrm{H}_{2} \mathrm{O}\right]$ and the appropriate phosphine ligands in the 1:2 molar ratio, as per the procedure described in the literature [31]. Phosphine ligands are known for use in the palladium-catalyzed amination reactions of aryl halides (TrippyPhos [38,39], BippyPhos [40,41]) and in the Suzuki and Sonogashira reactions and the $\alpha$-arylation of ketones (meCgPPh [42]). The complex (2) was characterized as a hydroamination catalyst of terminal alkynes in literature but it was obtained in a different way of synthesis from the one used in this manuscript [29]. Information about the structure of (3) has been placed in a private communication in CSD with GASLUK Refcode [30].

$\mathrm{X}$-ray data do not confirm the structure of the complex (1). Therefore, in this case, the formation of (1) was deduced on the basis of the obtained spectroscopic data $\left({ }^{1} \mathrm{H},{ }^{13} \mathrm{C},{ }^{31} \mathrm{P}\right.$ NMR, IR) and mass spectra analysis (FAB-MS). The selected spectra of (1) are depicted in Figures S1-S9 in the Supplementary Materials. Multinuclear magnetic resonance allowed us to verify the presence of a phosphine ligand in environment of the central atom and determine the mode of ligand binding method in complexes.

Considering the coordination of TrippyPhos to $\mathrm{Au}(\mathrm{I})$ (Figure 2), the comparison of the appropriate chemical shifts for the complex ( $\delta$ complex) to the free ligand ( $\delta$ ligand) enables the calculation of all the coordination shifts $(\Delta$ coord. $=\delta$ complex $-\delta$ ligand $)$ (Table 1$)$. 


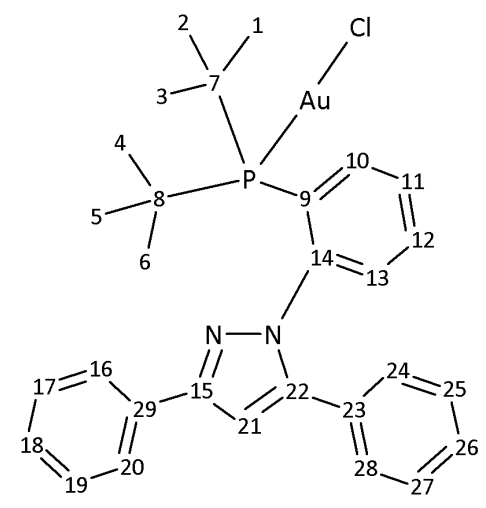

Figure 2. Complexes [Au(TrippyPhos)Cl] (1) with the numbering of the relevant atoms for the assignment of the appropriate to NMR data.

Table 1. ${ }^{1} \mathrm{H},{ }^{13} \mathrm{C}$ and ${ }^{31} \mathrm{P}$ nuclear magnetic resonance (NMR) chemical shifts of [Au(TrippyPhos)Cl] (1) complex and TrippyPhos in $\mathrm{CDCl}_{3}$. The coordination shifts are shown in parentheses *.

\begin{tabular}{|c|c|c|c|c|c|c|}
\hline Compound & $\begin{array}{c}\delta \mathrm{H}\left(\mathrm{CH}_{3}\right) \\
(t \mathrm{Bu})\end{array}$ & $\begin{array}{c}\delta \mathrm{C}(1-6)\left(\mathrm{CH}_{3}\right) \\
(t \mathrm{Bu})\end{array}$ & $\begin{array}{c}\delta C(7,8) \\
(t \mathrm{Bu})\end{array}$ & $\delta \mathrm{P}-\mathrm{C} 9(\mathrm{Ph})$ & $\delta(\mathrm{N}-\mathrm{C} 14(\mathrm{Ph}))$ & $\delta P$ \\
\hline (1) & $\begin{array}{c}1.13 d, 1.37 d \\
(+0.32,+0.28)\end{array}$ & $\begin{array}{c}31.5 \mathrm{~d}, 32.1 \mathrm{~d} \\
(+1.1,+1.7)\end{array}$ & $\begin{array}{c}39.0 \mathrm{~d}, 39.3 \mathrm{~d} \\
(+6.4,+6.7)\end{array}$ & $\begin{array}{c}133.1 \mathrm{~d} \\
(+3.0)\end{array}$ & $\begin{array}{l}142.2 \mathrm{~s} \\
(+6.0)\end{array}$ & $\begin{array}{c}57.6 \\
(+38.6)\end{array}$ \\
\hline TrippyPhos & $0.81,1.09$ & $30.4 \mathrm{~s}$ & $32.6 \mathrm{~s}$ & 130.1 & 136.2 & 19.0 \\
\hline
\end{tabular}

Upon coordination with the gold center, the $\mathrm{H}$ signals of $\mathrm{CH}_{3}(t \mathrm{Bu})$ in ${ }^{1} \mathrm{H}$ NMR appeared as two doublets and shifted to lower fields (Supplementary Materials Figures S1 and S2). This is caused by a different location of this group in space. The signals of aromatic hydrogens in $\mathbf{P h}-\mathrm{P}$ did not shift significantly (there were only slightly upfield shifts, approximately $0.1-0.2 \mathrm{ppm}$ ) and were at 7.19ppm. Other resonances remain mainly unchanged when compared to the spectra of the free phosphine. Coordination also leads to downfield shifts (approx. 1-2 ppm) of the $\mathrm{CH}_{3}(t \mathrm{Bu})$ (methyl groups), (approx. $7 \mathrm{ppm}$ ) the $\mathrm{C}(\mathrm{tBu}$ ), and the $\mathrm{P}-\mathrm{C}(\mathrm{Ph})(\mathrm{C} 9)$ (approx. $3 \mathrm{ppm}$ ) signals in ${ }^{13} \mathrm{C}$ NMR (Supplementary Materials Figures S3 and S4). Due to ${ }^{13} \mathrm{C}-{ }^{31} \mathrm{P}$ coupling, $t$ Bu carbons and two carbon atoms of $\mathbf{P h}-\mathrm{P}$ (C9 and C10) in the TrippyPhos ligand appeared as doublet resonances. Moreover, for each of these carbon occurred two doublets induced by a different location of carbon in space. A significant change followed for C14 (downfield shift; approx. $7 \mathrm{ppm}$ ) that is bonding with nitrogen, which is connected with the change of charge density distribution after coordination. However, C15, C22 i C29 showed two signals and resonance values were higher with respect to that of the free ligand. The significant downfield shift of the ${ }^{31} \mathrm{P}$ signal was observed from $19.0 \mathrm{ppm}$ in uncoordinated TrippyPhos to $57.6 \mathrm{ppm}$ in complex pointing towards a strong metal phosphine interaction, and creating $\mathrm{Au}-\mathrm{P}$ bond (Supplementary Materials, Figures S5 and S6).

Moreover, the NMR analysis verified the X-ray data of (2), (3), and showed the same coordination mode of a phosphine ligand in a solution as in a solid state. Present signals confirmed $\mathrm{CH}_{2} \mathrm{Cl}_{2}$ in complex (2) at 5.48 , and $59.7 \mathrm{ppm}$ in ${ }^{1} \mathrm{H}$ and ${ }^{13} \mathrm{C} \mathrm{NMR}$, respectively. The most significant changes after the ligand coordination occur, as expected, in $\mathrm{P}-\mathrm{C}$ binding. Therefore, this comparison of ${ }^{31} \mathrm{P}$ signal of a ligand with a suitable complex showed the downfield shift $46.2 \mathrm{ppm}$ for (2) and $49.4 \mathrm{ppm}$ for (3), which confirms the coordination of a phosphine ligand. (Supplementary Materials, Figures S10 and S11).

Characteristic IR frequency bands of (1), (2), and (3) complexes, phosphine ligands and their assignments are given in Table S2 (Supplementary Materials). The presence bands of the $v(\mathrm{Au}-\mathrm{P})$ and suitable spectral shifting of the $v(\mathrm{P}-\mathrm{C})$ after the complexation with metal ions in comparison to the free ligand confirmed the coordination of a phosphine 
ligand to the gold atom through $\mathrm{P}$ donor atom. According to the literature [43], v(Au-P) was assigned to the band in the $420-541 \mathrm{~cm}^{-1}$ region for all complexes. The characteristic stretching bands of $v(\mathrm{P}-\mathrm{C})$ of the ligands were found at about 1450, 960, 750, 690, 600, 520, $470 \mathrm{~cm}^{-1}$, and usually were shifted in higher frequencies of the spectra. However, taking into consideration intensive and broad ligand bands at 694,694, $704 \mathrm{~cm}^{-1}$, shifts after coordination were $5,2,4 \mathrm{~cm}^{-1}$ for (1), (2), and (3), respectively. This was a shift towards lower frequencies. The following bands of $v(P-C)$ in the range from 780 to $730 \mathrm{~cm}^{-1}$ appeared as two peaks for ligands-TrippyPhos $\left(777,756 \mathrm{~cm}^{-1}\right)$ and BippyPhos (780, $762 \mathrm{~cm}^{-1}$ ) but after coordination it was one peak at $764,775 \mathrm{~cm}^{-1}$ for (1) and (2) complexes, respectively. By contrast, for complex (3) bands at 757, $728 \mathrm{~cm}^{-1}$ but for meCgPPh at $747 \mathrm{~cm}^{-1}$ were observed. All changes were probably caused by the increase of the electron density on the gold center and the change of charge density distribution in suitable organic ligand after its coordination. The existence of aromatic rings in a structure is determined by $\mathrm{C}-\mathrm{H}$, and $\mathrm{C}=\mathrm{C}-\mathrm{C}$ ring-related vibrations in the range $3100-2992$, and $1265-1125 \mathrm{~cm}^{-1}$. Vibrations at about 2960-2869 are assigned to the $\mathrm{C}-\mathrm{H}$ aliphatic group. The band of $v(\mathrm{C}-\mathrm{H})$ stretching vibration in the plane and out of the plane of the phenyl group appeared at about 1020 and $750 \mathrm{~cm}^{-1}$. The strong methyl bands, showing significant splitting of the band in the range 1350-1420 $\mathrm{cm}^{-1}$ indicative of the tert-butyl group [44] verified its presence in (1) and (2) complexes. Moreover, (1) and (2) complexes and their pyrazole-phosphine ligand showed intense bands at approximately 1600,1470, and $1160 \mathrm{~cm}^{-1}$, which were assigned to stretching bands of the $\mathrm{C}-\mathrm{N}, \mathrm{C}=\mathrm{N}$, and $\mathrm{N}-\mathrm{N}$ vibrations, respectively. Additionally, the presence of a phosphine ligand in complex (3) was confirmed by stretching bands $v(\mathrm{C}-\mathrm{O}-\mathrm{C})$ at $1210,1280,1130$, and $1080 \mathrm{~cm}^{-1}$.

The FAB-MS spectrum of complexes (1)-(3) showed suitable molecular ion peaks, which corresponded to the expected molecular weights and fragmentation patterns in accordance with the molecular formulae of this complexes. The FAB-MS is a very useful method that provides structural information of new complexes when the X-ray analysis is impossible to carry out. Positive-ion FAB-MS analysis of (1) (Supplementary Materials, Figure S7) showed a molecular ion peak $\left[\mathrm{M}^{+}\right] \mathrm{m} / z=673.0$, which corresponds to the molecular formula of its parent ion [TrippyPhosAuCl] ${ }^{+}$. Other results showed fragmentation at: $\mathrm{m} / \mathrm{z}$ 136.0 $\left[\mathrm{Ph}-\mathrm{PCH}=\mathrm{CH}_{3}\right]^{+}, 147.0\left[\mathrm{H}_{2} \mathrm{P}\left(\mathrm{Bu}^{\mathrm{t}}\right)_{2}\right]^{+}, 207.0\left[\mathrm{PhC}=\mathrm{NH}_{2}(\mathrm{Ph})\right]^{+}, 232.1[\mathrm{Au}-\mathrm{ClH}]^{+}, 292.0$

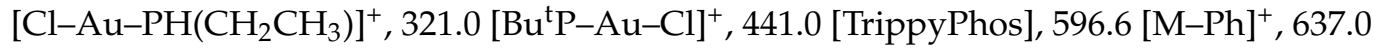
$[\mathrm{M}-\mathrm{Cl}]^{+}$.

As shown in these examples, fragmentation can be used to obtain information regarding the structure and the bond nature of the desired compound. The results of mass spectrum analysis and spectroscopy method (NMR, IR) of (1) were applied to determine the environment of the central atom and the mode of the ligand binding method in (1). Thus, they provided evidence for the new gold(I) phosphine complex.

\subsection{Crystal Structures of (2) and (3)}

[Au(BippyPhos) $\mathrm{Cl}] \cdot 0.5 \mathrm{CH}_{2} \mathrm{Cl}_{2}$ (2) crystallized in the monoclinic $\mathrm{P} 21$ space group with all atoms in general positions and the whole molecule given by the formulae in the asymmetric unit (Supplementary Materials, Figure S12). The details about refinement are presented in Table S1 (Supplementary Materials). The structure of (2) is identical to the previously reported model [29] with $\mathrm{Au}(\mathrm{I})$ in linear coordination with chloride and phosphorus in the coordination sphere (structure details are given in the Supplementary Materials, Table S3). However, the original structure was mentioned briefly without a detailed description and the paper was focused on terminal alkynes hydrohydrazination with gold(I) complexes as catalysts. Therefore, we also decided to report this structure and describe details of interactions in its crystal network. In the reported compound $\mathrm{Au}-\mathrm{Cl}$ bond length is similar to those with terminal chlorides being 2.2925(8) $\AA$ for $\left[\mathrm{AuCl}\left(\mathrm{Ph}_{3} \mathrm{P}=\mathrm{C}(\mathrm{CN}) \mathrm{P}(\mathrm{tBu})_{2}\right)\right][45]$, 2.3144(6) $\AA$ for $\left[\mathrm{AuCl}\left(\mathrm{cy}_{3} \mathrm{PCH}_{3} \mathrm{P}(\mathrm{tBu})_{2}\right)\right], 2.284 \AA$ for $\left[\mathrm{AuCl}\left(\mathrm{P}(\mathrm{tBu})_{3}\right)\right][46], 2.287(3)$ and 2.293(3) A for [AuCl(L1)] (L1-(R,R)-2,5-bis(trifluoromethyl)phenyl]-1-[2' -(di-t-buthylphospanyl) [1,1'-biphenyl]-4-yl]pyrrolidine) [47] 2.2906(5) $\AA$ for $\left[(\mathrm{AuCl})_{2} \mathrm{~L} 2\right]\left(\mathrm{L} 2-\left(\mu-1,1^{\prime}\right.\right.$-bis(di-tert- 
butylphosphanyl)ferrocene)) [48]. Chlorido bridges occurring between gold(I) cations result in elongation of the $\mathrm{Au}-\mathrm{Cl}$ bonds by approximately $0.06 \AA$ being 2.3624(15) and 2.3525(19) $\AA$ for $\left[\mathrm{Au}_{2}(\mu-\mathrm{Cl})(\mathrm{L} 1)_{2}\right]\left(\mathrm{B}\left(3,5-\mathrm{CF}_{3} \mathrm{Ph}\right)_{4}\right) \cdot$ solvate [47] 2.3776(3) and 2.3867(3) $\AA$

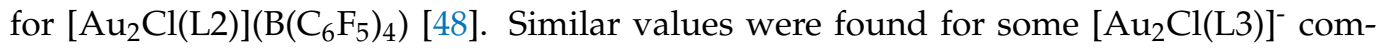
plexes (L3-bis(biphenyl-2-yl(di-tert-butyl)phosphine)) with tetrafluoroborate (2.3478(4) and 2.3512(14) $\AA$ ), bis(trifluoromethanesulfonyl)imide (2.3524(14) and 2.3548(14) $\AA$ ), hexafluoroantimony $(2.3560(11)$ and 2.3802(11) $\AA$ ) and trifluoromethanesulfonate (2.3588(19) and 2.3461(19) $\AA$ ) [49]. In $\left[\mathrm{Au}_{2} \mathrm{Cl}\left(\mathrm{P}^{\mathrm{t}} \mathrm{Bu}_{3}\right)_{2}\right]\left(\mathrm{SbF}_{6}\right), \mathrm{Au}-\mathrm{Cl}$ bonds were 2.339(2) and 2.344(2) $\AA$ [50]. Hence, in all those dimer units with usually similar and short $\mathrm{Au}-\mathrm{Au}$ distances indicating on aurophilic interactions, $\mathrm{Au}-\mathrm{Cl}$ distances fall into a very narrow range. $\mathrm{Ex}-$ tremely long values were found for structures with bridging chloride and gold(I) occurring in tricoordinated environment: 2.6324(13) for [ $\mathrm{AuCl}(\mathrm{L} 4)]$ (L4-9,9-dimethyl-4,5-bis(di-tertbutylphosphino)xanthene) and 2.6495(8) $\AA$ for $[\mathrm{AuCl}(\mathrm{L} 4)] \cdot \mathrm{C}_{6} \mathrm{~F}_{5} \mathrm{NO}_{2}$. In all those compounds, $\mathrm{Au}-\mathrm{P}$ bonds are similar and range from 2.34 to $2.37 \AA$ apart from tricoordinated gold(I) complexes with values ranging from 2.3200(10) to 2.3333(11) ^̊ [51]. Similarly, for tricoordinated complexes $\mathrm{P}-\mathrm{Au}-\mathrm{Cl}$ angles fall into the range from 106.56(4) to $112.89(4)^{\circ}$, whereas in most cases, they are close to a linear atom arrangement. In auranofin with potential anti-cancer properties based on gold(I) complex with triethylphosphine and sulfur ligand [52], the Au-P bond length is $2.259 \AA$ whereas $\mathrm{Au}-\mathrm{S}$ is $2.293 \AA$. The former is significantly shorter than in all the discussed structures. The latter is similar to $\mathrm{Au}-\mathrm{Cl}$ bonds in monomeric species and the arrangement of both ligands in auranofin is also almost linear $\left(173.6^{\circ}\right)$.

All rings remain flat with rms deviation ranging from $0.014 \AA$ for C31 phenyl ring to $0.019 \AA$ for C21 phenyl ring and only N14 pyrazole ring shows a significantly smaller deviation $(0.007 \AA)$. N14 ring is almost perpendicularly oriented to other rings apart from C41 phenyl ring $\left(33.1^{\circ}\right)$. The central N18 ring is strongly inclined to other rings acting as substituents with values being 85.2 (N14 pyrazole), 35.1 (C21 phenyl), 50.0 (C31 phenyl) and $59.6^{\circ}$ (C41 phenyl). The mutual orientation of these rings also depends on created interactions, namely two intramolecular hydrogen bonds (C26-H26 ... N14 and C42$\mathrm{H} 42$.. Cl2). Dialkylbiarylphosphines are known as electron reach ligands and, due to steric hindrance, they are able to stabilize gold(I) complexes via intramolecular $\mathrm{Au}-\pi$ interactions [45]. The reported structure is stabilized by such interactions between Au1 and C16 pyrazole ring imposing a conformation with the $\mathrm{Cl}-\mathrm{Au}-\mathrm{P}$ line being approximately parallel to the line crossing both pyrazole rings as it was observed for biphenyl systems [47]. Due to the large organic ligand, a separation between adjacent $\mathrm{Au}(\mathrm{I})$ ions is significant with the shortest distance being $8.187 \AA$ impairing aurophilic interactions. In the crystal network, the packing shows chains of units running along $\mathrm{b}$ axis with angles between adjacent $\mathrm{Au}(\mathrm{I})$ cations being $80.67^{\circ}$ and solvent molecules accounting for $18.4 \%$ of the cell volume and located in voids between these chains (Figure 3 ). The analysis of fingerprint plots provided by CrystalExplorer $[53,54]$ and the $d_{\text {norm }}$ Hirshfeld surface show that $H$ ... H interactions are the most numerous (59.9\%). However, due to interaction nature $\mathrm{H} \ldots \mathrm{Cl}$ is the most important interactions occurring between gold(I) complexes $(17.6 \%$ interactions). In contrast, $\mathrm{N} \ldots \mathrm{H}$ interactions are much less numerous $(5.2 \%)$ and much weaker (Supplementary Materials Figure S13). In bc layers the gold(I) moieties interacts via C6-H6A ... Cl2[2 - x, $-0.5+\mathrm{y}, 2-\mathrm{z}]$ and C34-H34 ... Cl2[2- x, $0.5+\mathrm{y}, 1-\mathrm{z}]$ hydrogen bonds and stacking interactions between two $\mathrm{C} 31$ phenyl rings. The dichloromethane molecules captured in the network voids form C24- H24 .. Cl4[1 - x, $-0.5+y, 2-z]$ hydrogen bond. The adjacent layers are coupled by $\pi-\pi$ interactions between two $\mathrm{C} 21$ and two C41 phenyl rings and $\mathrm{C} 44-\mathrm{H} 44 \ldots \pi$ interactions with $\mathrm{N} 18$ pyrazole ring. 


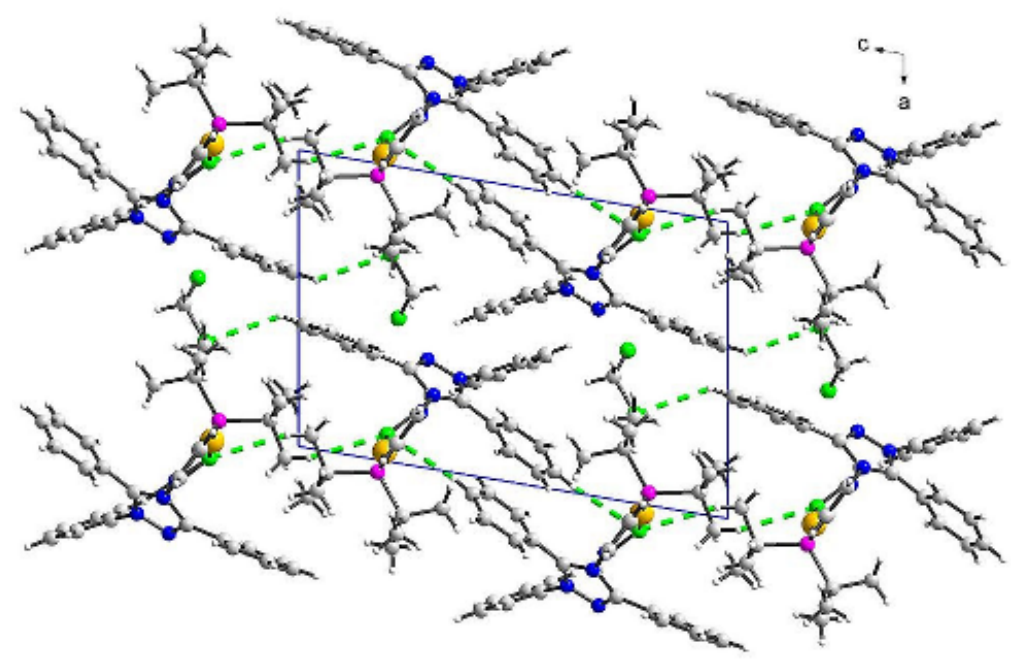

Figure 3. The crystal network viewed along $\mathrm{b}$ axis for (2). $\mathrm{C}-\mathrm{H} \ldots \mathrm{Cl}$ hydrogen bonds marked by dotted green lines show bc layers.

[Au(meCgPPh)Cl] (3) crystallized in the monoclinic $\mathrm{P} 2{ }_{1} / \mathrm{n}$ space group with all atoms in general positions and the whole molecule given by the formulae in the asymmetric unit (Figure 4). The details about refinement are presented in Table S2 (Supplementary Materials). Selected bond lengths and angles for $\mathrm{Au}(\mathrm{I})$ coordination spheres in (3) are given in the Supplementary Materials, Table S3. In (3) gold(I) adopts linear coordination with chloride and phosphorous as donor atoms. They were found at 2.2221(10) and 2.2692(11) $\AA$ for phosphorous and chloride, respectively, and the $\mathrm{P}-\mathrm{Au}-\mathrm{Cl}$ angle was almost linear $\left(176.49(4)^{\circ}\right)$. The former bond length is significantly shorter than in the auranofin whereas $\mathrm{Au}-\mathrm{S}$ is only slightly longer than $\mathrm{Au}-\mathrm{Cl}$ in (3) [52]. Both bond lengths fall into ranges observed for complexes with [AuCl(trioxaphosphaadamantane] motif with $\mathrm{Au}-\mathrm{Cl}$ and $\mathrm{Au}-$ $\mathrm{P}$ bonds being 2.2704(19) and 2.2137(18) $\AA$ for [ $\mathrm{Au}(\alpha-\mathrm{CgPAmHMe}) \mathrm{Cl}] \mathrm{BF}_{4}(\alpha-\mathrm{CgPAmHMe}-$ 4,5,8,8-tetramethyl-2-(1,3,5,7-tetramethyl-2,4,6-trioxa-8-phosphatricyclo [3.3.1.1]decan-8yl)-2,4-diazabicyclo[3.2.1] oct-2-en-2-ium-3-yl) [55] as well as 2.2930(9) and 2.2285(8) for [AuCl(L5)] (L5-8-(2-[bis(2-methylphenyl)phosphanyl]phenyl)-1,3,5,7-tetramethyl-2,4,6trioxa-8 phosphatricyclo[3.3.1.13,7]decane), whereas for gold(I) dimers with aurophilic interactions they are 2.2863(16) and 2.2375(13) $\AA$ for $\left[\mathrm{Au}_{2} \mathrm{Cl}_{2}(\mathrm{~L} 5)\right] \cdot \mathrm{Et}_{2} \mathrm{O}$ [29] as well as 2.2919(16) and 2.2328(16) $\AA$ for $\left[\mathrm{Ph}_{2} \mathrm{P}(\mathrm{AuCl})\left(\mathrm{CH}_{2}\right)_{2} \mathrm{PAd}(\mathrm{AuCl})\right]$ (HPAd-1,3,5,7-tetramethyl2,4,8-trioxa-6-phosphaadamantane) [56].

The C1 phenyl ring is flat within $0.008 \AA$ and it is not involved in any $\pi-\pi$ interactions because it is buried between trioxaphosphaadamantane moieties and chloride anions. The latter enables hydrogen bond formation with the $\mathrm{H} 3$ atom. In packing a dimer composed of hydrogen bonded (C23-H23A ... Cl2[1 - x, $-\mathrm{y}, 1-\mathrm{z}]$ and C19-H19B ... Cl2[1 - x, $-y, 1-z])$ moieties is a dominating motif whereas other intermetallic distances are much longer (Figure 5). Nevertheless, the aurophilic interaction is also absent in such a dimer due to a long Au-Au separation (5.464 $\AA$ ). Hence, in (3) the crystal network is maintained by $\mathrm{C}-\mathrm{H} \ldots \mathrm{Cl} 2$ hydrogen bonds with hydrogen atoms coming from aromatic $\mathrm{CH}$ and aliphatic $\mathrm{CH}_{2}$ and $\mathrm{CH}_{3}$ groups. The analysis performed in CrystalExplorer $[53,54]$ showed the presence of numerous weak interactions and also another hydrogen bond between $\mathrm{C} 21-\mathrm{H} 21 \mathrm{C}$ and $\mathrm{O} 14[1-\mathrm{x},-\mathrm{y},-\mathrm{z}]$ marked as a spike on the fingerprint. It is also clear that the crucial interactions are $\mathrm{Cl} \ldots \mathrm{H}(18.6 \%)$ and $\mathrm{O} \ldots \mathrm{H}(8.6 \%)$ because these donor atoms are involved in hydrogen bonding (Supplementary Materials Figure S14). 


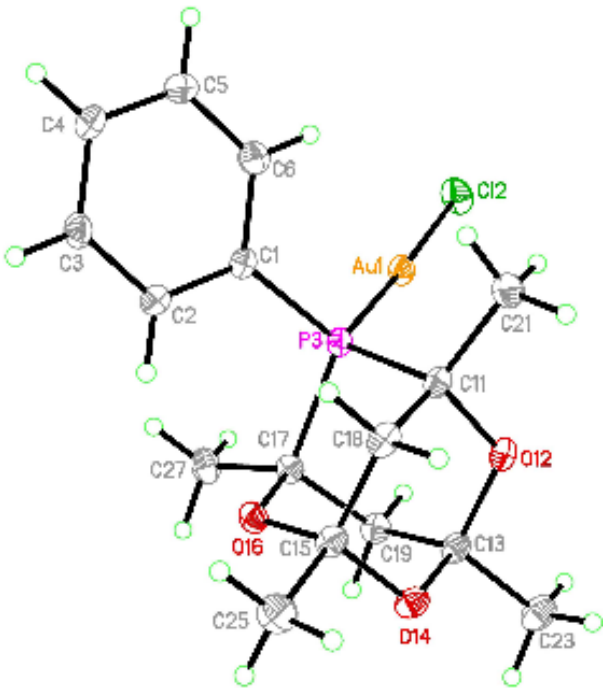

Figure 4. Structure of (3) with numbering scheme and thermal ellipsoids at $20 \%$ probability.

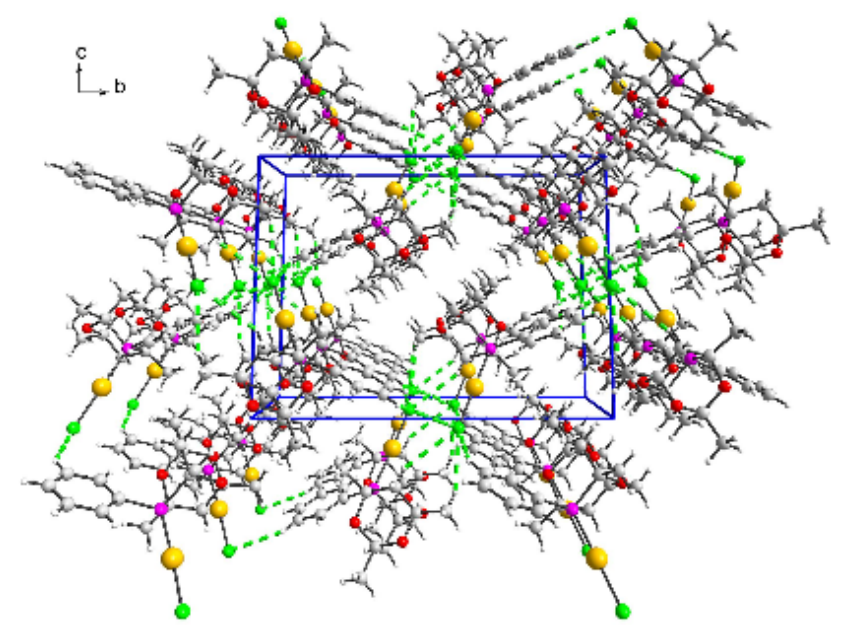

Figure 5. Perspective view of the packing along a axis for (3). C-H .. Cl hydrogen bonds are marked by dotted green lines.

\subsection{Solution Stability and Lipophilicity}

Anti-cancer drugs should be stable and should not decompose before reaching their biological targets. The stability of metal complexes in physiological and biological mediums is significant for the efficiency of the potential chemotherapeutics action. Therefore, the stability of the gold(I) phosphine complexes under physiological-like conditions was estimated by monitoring the electronic spectra in a phosphate-buffered saline (PBS). Moreover, UV-Vis spectra were measured in a cell culture medium, which contains FCS. All spectra were collected over $48 \mathrm{~h}$. The spectra of the complexes (1)-(3) are shown in Figure 6. 

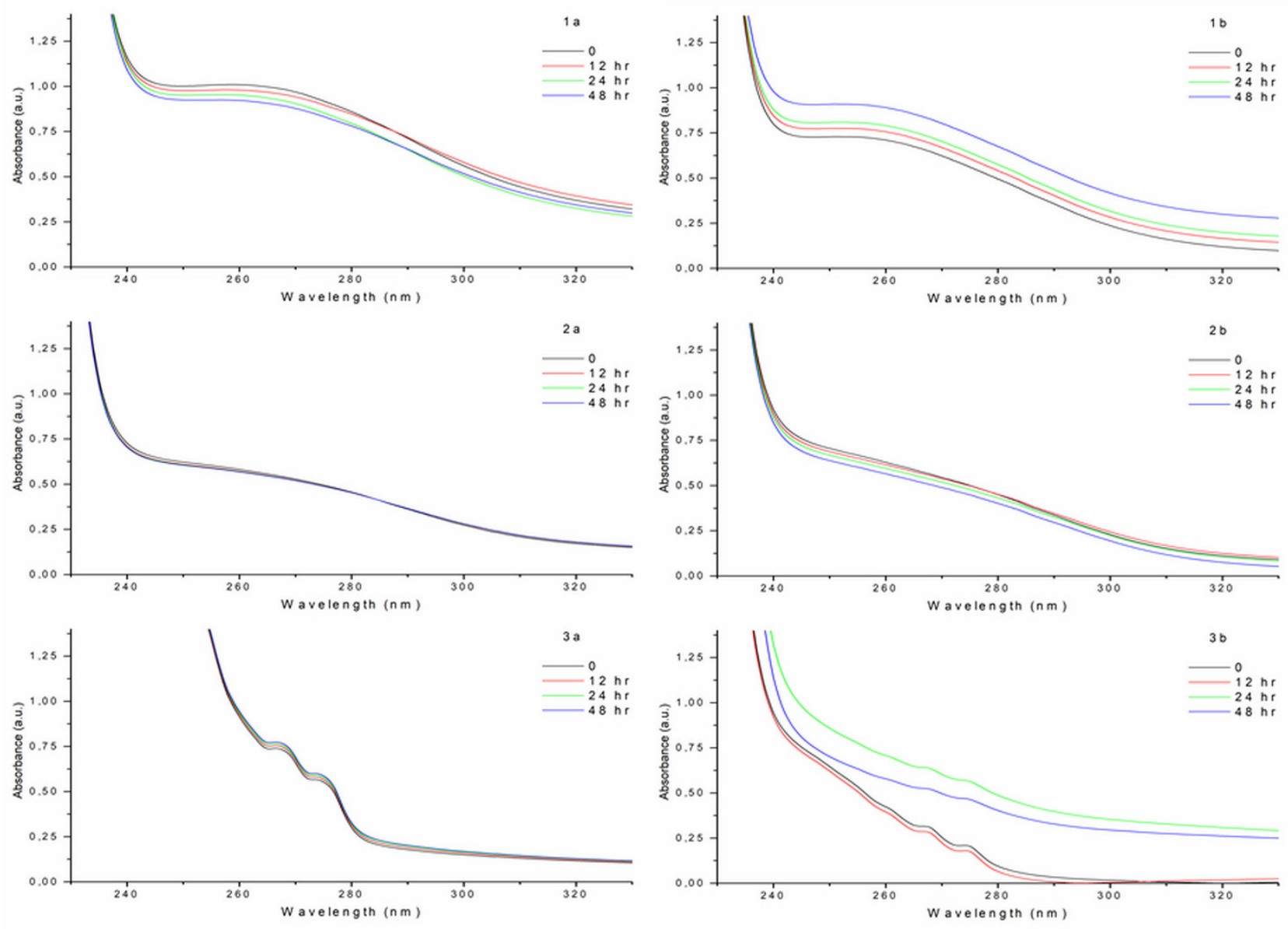

Figure 6. Ultraviolet-visible (UV-Vis) absorption spectra of the gold(I) complexes $(50 \mu \mathrm{M})$ in phosphate-buffered saline (PBS) (1a-3a) and in cell culture medium $(\mathbf{1} \mathbf{b}-\mathbf{3 b})$ over $48 \mathrm{~h}$.

According to literature data [57], the high-energy bands observed in the UV-Vis spectra of (1)-(3) may be attributed to the ligand-to-metal charge transfer (LMCT) or metalto-ligand charge-transfer (MLCT) character of the $\mathrm{Au}(\mathrm{I})$ center. A broad absorption band was noticeable for compound (1) at 268 and (2) at $272 \mathrm{~nm}$. By contrast, for complex (3) there are two bands at 270 and $276 \mathrm{~nm}$.

In the spectra of complexes (1) and (3) (phosphate-buffered saline, PBS), we observed a slightly decreasing the intensity of spectral bands, whereas in spectra of complexes (1) the changes were the largest. In contrast, complex (2) showed no change in absorption bands. These changes suggest a slow hydrolysis process under these conditions for complexes (1) and (3). However, minor changes were observed in the cell culture medium particularly for (3). Complex (2) was the most stable. This probably means that gold(I) phosphine complexes (1) and (3) react with biomolecules in cell culture medium.

Lipophilicity is an important physicochemical property of compounds with potential biological activity, which affects cellular uptakes and ADMET (absorption, distribution, metabolism, excretion, toxicity) behavior and can be determined by the $\log P$ value. Lipophilicity depends on the structural properties of compounds associated with hydrophobic and dispersive forces, electrostatic interactions and hydrogen bonds $[58,59]$. The optimal region of $\log \mathrm{P}$ for therapeutic agents is proposed within the range of 1-3 [60]. According to the literature [61], molecules of potential drugs with optimal lipophilicity tend to exhibit the best pharmacokinetic properties. Optimal lipophilicity allows for the appropriate transport through biological membranes and binding to molecular targets and, as a consequence, a better cellular accumulation and biological activity. The compounds 
that can cross the blood-brain barrier (BBB) show lipophilicity in the range from 1.7 to 2.8 [62]. However, in the case of cancer cells a simple correlation between increasing lipophilicity, cellular accumulation and cytotoxicity cannot always be observed [63].

The estimated partition coefficient $(\log \mathrm{P})$ values of complexes (1)-(3) were in the range 2.4-3.4, demonstrating their lipophilic character. The highest value of $\log \mathrm{P}$ was equal to $3.43 \pm 0.15$ for (3); lipophilicity of (1) and (2) was lower and equal to $2.98 \pm 0.11$ and $2.45 \pm 0.05$, respectively. These values of $\log P$ are determined by structural properties of complexes and particularly their ligands, and presumably influence their biological activity, e.g., cytotoxicity.

\subsection{Cytotoxic Effect of Phosphine Gold(I) Complexes}

The cytotoxic effect of the tested phosphine gold(I) complexes was assessed by determining cellular succinate dehydrogenase activity with the MTT assay after $48 \mathrm{~h}$ incubation of cells with test compounds. It has been shown that the studied complexes exert a cell linedependent cytotoxicity (Table 2). The compounds (1) and (2) weakly affected the viability of estrogen receptor-negative MDA-MB-231 cells in comparison to cisplatin. Compound (3) was not active against HeLa, K562 and A549 cells. However, it influenced the viability of MDA-MB-231, A2780 and A2780cis cell lines to a similar level as auranofin.

Table 2. Cytotoxic activity of studied compounds against HeLa (human cervix carcinoma), K562, A549, MDA-MB-231, A2780, A2780cis, and HUVEC (human umbilical vein endothelial) cells after $48 \mathrm{~h}$ exposure. IC $_{50}$ values are means \pm SD of three independent experiments.

\begin{tabular}{cccccccc}
\hline \multirow{2}{*}{ Compound } & \multicolumn{7}{c}{ IC $_{\text {50 }}[\boldsymbol{\mu M}]$} \\
\cline { 2 - 8 } & HeLa & K562 & A549 & MDA-MB-231 & A2780 & A2780cis & HUVEC \\
\hline 1 & $1.7 \pm 0.9$ & $0.5 \pm 0.4$ & $0.8 \pm 0.3$ & $10.7 \pm 3.0$ & $1.42 \pm 0.14^{*}$ & $7.05 \pm 0.67$ & $2.00 \pm 0.07$ \\
2 & $3.0 \pm 0.8$ & $1.5 \pm 1.0$ & $5.0 \pm 2.6$ & $13.4 \pm 3.9$ & $1.67 \pm 0.51$ & $3.03 \pm 0.35$ & $27 \pm 0.56$ \\
3 & $22 \pm 5.3$ & $15 \pm 3.1$ & $19 \pm 2.9$ & $5.50 \pm 0.25$ & $2.8 \pm 0.43$ & $2.23 \pm 0.25$ & $5.5 \pm 0.44$ \\
auranofin & $0.8 \pm 0.1$ & $0.3 \pm 0.04$ & $3.0 \pm 0.3$ & $5.43 \pm 0.95$ & $2.32 \pm 0.19$ & $3.68 \pm 0.08$ & $0.27 \pm 0.01$ \\
cis-Pt & $20 \pm 6.0$ & $40 \pm 7.0$ & $30 \pm 6.5$ & $0.79 \pm 0.24$ & $4.45 \pm 0.78$ & $33.33 \pm 0.94$ & $30 \pm 6.5$ \\
\hline
\end{tabular}

* The differences between $\mathrm{IC}_{50}$ values for (1) and reference compounds: auranofin and cisPT are statistically significant $(p<0.05)$.

\subsection{Thioredoxin Reductase Activity in A2780 and A2780cis Cells}

Tumor sensitivity or resistance to auranofin and cisplatin observed in cancer cell lines in vitro may be related to the level of intracellular thioredoxin reductase (TrxR) activity [64]. Our studies confirm a higher TrxR activity (2.3-fold) in resistance to cisplatin cell line A2780cis in comparison to sensitive cells A2780 (Table 3). The difference in the activities of NADPH-dependent reductases (TrxR, glutathione reductase, glutathione peroxidase) as a whole was less significant (1.9-fold).

Table 3. Basal thioredoxin reductase activity in A2780 and A2780cis cells. The results are expressed as means $\pm \operatorname{SD}(n=3)$.

\begin{tabular}{ccc}
\hline Cell Line & $\begin{array}{c}\text { NADPH-Dependent Reductases } \\
\text { [Unit/10 }\end{array}$ Cells \pm SD] & $\begin{array}{c}\text { TrxR Activity } \\
\text { [Unit/10 }\end{array}$ Cells \pm SD] \\
A2780 & $0.69 \pm 0.17$ & $0.270 \pm 0.078$ \\
A2780cis & $1.28 \pm 0.19$ & $0.629 \pm 0.102$ \\
\hline
\end{tabular}

The complexes (1), (2) and (3) inhibited rat's liver TrxR activity with $\mathrm{IC}_{50}$ at the micromolar level. In the present study, the effect of gold complexes on the activity of NADPH-dependent reductases in cytosol isolated from A2780 and A2780cis cells was estimated. The studied compounds at the concentration of $10 \mu \mathrm{M}$ inhibited the activity of NADPH-dependent reductases in the cytosol of both A2780 and A2780cis cells. However, the inhibitory effect demonstrated by auranofin, complex (1) and (2) was more pronounced in cisplatin-resistant cells; in the case of complex (2) the difference was statistically significant (Figure 7). 


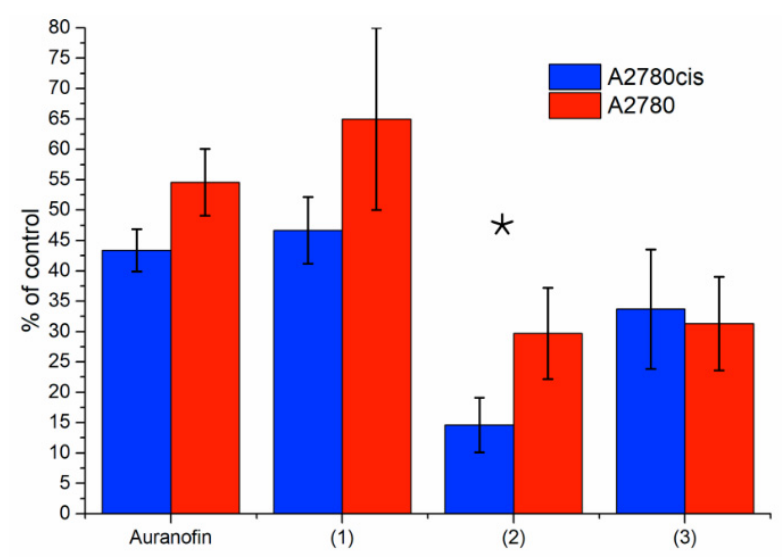

Figure 7. Inhibition of the activity of NADPH-dependent reductases in cytosol of A2780 and A2780cis cells by gold(I) phosphine complexes expressed as a \% of control. Studied compounds were added at final concentration $10 \mu \mathrm{M}$. DMSO was added to the control samples as a solvent. Data represent the mean \pm SD of three independent experiments. * Difference between mean values of $\%$ of inhibition determined in A2780 and A2780cis cells is statistically significant $(p<0.05)$.

Based on our preliminary research results, we can suggest that both the differences in physicochemical and biological properties may be related to the type of ligand in the complex as well as the mode of the ligand binding in complexes. The mechanism of action of anti-cancer gold(I) complexes so far has not been fully explained. However, it may involve the inhibition of the glutathione reductase-like enzyme thioredoxin reductase (TrxR) [3]. According to literature data [65,66], auranofin and other gold(I) phosphine complexes, such as ([AuCl( $\left.\left.\mathrm{PPh}_{3}\right)\right]$ ) release S-donor ligand (auranofin) or chlorido ligand $\left(\left[\mathrm{AuCl}\left(\mathrm{PPh}_{3}\right)\right]\right)$ under physiological conditions form $\left[\mathrm{Au}\left(\mathrm{PR}_{3}\right)\right]^{+}$species which can react with various biomolecules (e.g., albumin, $\mathrm{AlbH}$ or glutathione, GSH). Moreover, it was proved that a phosphine ligand could be released when auranofin and $\left[\mathrm{AuCl}\left(\mathrm{PPh}_{3}\right)\right]$ interact with biomolecules and form species such as $\left[\mathrm{Au}(\mathrm{SG})_{2}\right]^{-}$or $\left[\mathrm{Au}(\mathrm{Alb})_{2}\right]^{-}[67,68]$.

According to literature [69], replacing the halide in $\mathrm{Au}-\mathrm{Cl}$ by the protein is favored over replacing a phosphine ligand, but both are possible. In the case of our preliminary study, we can speculate that the longer $\mathrm{Au}-\mathrm{Cl}$ bond in complex (2) (2.285 $\AA$ ) than $\mathrm{Au}-$ $\mathrm{P}(2.247 \AA)$ will allow for an easier exchange of the chloride ligand than phosphine on biomolecules and further interaction with proteins. Moreover, $\mathrm{Au}-\mathrm{Cl}$ and $\mathrm{Au}-\mathrm{P}$ for (2) are longer than for (3) but comparable to $\mathrm{Au}-\mathrm{S}$ and $\mathrm{Au}-\mathrm{P}$ in auranofin. This may affect the similarity of (2) and auranofin in biological activity. However, complex (2) showed high and selective cytotoxic activity and the highest inhibitory abilities among the analyzed compounds, requiring further detailed biological research.

\section{Conclusions}

In summary, the gold(I) phosphine complexes [Au(TrippyPhos)Cl] (1) [Au(BippyPhos)Cl] $.0 .5 \mathrm{CH}_{2} \mathrm{Cl}_{2}$ (2) and $[\mathrm{Au}(\mathrm{meCgPPh}) \mathrm{Cl}](3)$ were synthesized, and their structures were determined and characterized by means of spectroscopic techniques (FTIR, ${ }^{1} \mathrm{H},{ }^{13} \mathrm{C},{ }^{31} \mathrm{P} N M R$ ), elemental analysis and mass spectrometry (FAB-MS). Additionally, the solid-state crystal structures of complexes (2) and (3) were confirmed using X-ray analysis. The study of gold(I) phosphine complexes in buffer saline (PBS) and in cell culture medium showed that complex (2) exerts the highest stability in both types of environment. The $\log P$ values of complexes (1) and (2) were in the optimal region for therapeutic agents.

The biological properties of the gold(I) complexes studied indicate a strong cytotoxic effect against cell lines A2780 and A2780cis. The cytotoxic effect for these cells was more pronounced than cisplatin, a therapeutic agent against ovarian cancer used in the present study as a reference. Moreover, complexes (1) and (2) exerted a significant cytotoxic effect against HeLa, K562 and A549 cells. 
Complex (2) was significantly less effective $\left(\mathrm{IC}_{50}=27.0 \mu \mathrm{M}\right)$ against the normal HUVEC cells exhibiting the best selectivity against cancer cells. Complex (3) showed the highest cytotoxicity against cancer cells resistant to cisplatin: 15-fold higher than cisplatin. Preliminary studies showed the inhibitory effect of gold complexes on the activity of cytosolic NADPH-dependent reductases in A2780 and A2780cis cells-the most pronounced being in the case of compound (2). This result, and the high cytotoxicity and selectivity of complex (2), may be related to its stability and optimal lipophilicity resulting from the structural properties of a ligand. The results qualify the chloro-phosphine gold(I) complexes under study for further extended research on their anti-carcinogenic activities and pharmacokinetic properties in order to determine their potential in cancer therapy.

Supplementary Materials: The following are available online at https:/ / www.mdpi.com/article/10.3 390/pr9122100/s1, Table S1: Crystal data and structure refinement for [Au(BippyPhos) $\mathrm{Cl}] \cdot 0.5 \mathrm{CH}_{2} \mathrm{Cl}_{2}$ (2), [Au(meCgPPh)Cl] (3). Figure S1: ${ }^{1} \mathrm{H}$ NMR of [Au(TrippyPhos)Cl] (1). Figure S2: ${ }^{1} \mathrm{H}$ NMR of TrippyPhos. Figure S3: ${ }^{13} \mathrm{C}$ NMR of [Au(TrippyPhos)Cl] (1). Figure S4: ${ }^{13} \mathrm{C}$ NMR of TrippyPhos. Figure S5: ${ }^{31} \mathrm{P}$ NMR of [Au(TrippyPhos)Cl] (1). Figure S6: ${ }^{31} \mathrm{P}$ NMR of TrippyPhos. Figure S7: FABMS of [Au(TrippyPhos)Cl] (1). Figure S8: IR of [Au(TrippyPhos)Cl](1). Figure S9: IR of TrippyPhos. Figure S10: ${ }^{31} \mathrm{P}$ NMR of [Au(BippyPhos)Cl] $0.5 \mathrm{CH}_{2} \mathrm{Cl}_{2}(\mathbf{2})(\mathbf{a})$ and BippyPhos (b). Figure S11: ${ }^{31} \mathrm{P}$ NMR of [Au(meCgPPh)Cl] (3) (a) and meCgPPh (b). Table S2: IR spectral data of [Au(TrippyPhos)Cl] (1), [Au(BippyPhos)Cl] $0.5 \mathrm{CH}_{2} \mathrm{Cl}_{2}$ (2), [ $\left.\mathrm{Au}(\mathrm{meCgPPh}) \mathrm{Cl}\right]$ (3). Figure S12: Structure of (2) with numbering scheme and thermal ellipsoids at 20\% probability. Table S3: Selected bond lengths $[\AA]$ and angles $\left[{ }^{\circ}\right]$ for $\mathrm{Au}(\mathrm{I})$ coordination spheres in $[\mathrm{Au}(\mathrm{BippyPhos}) \mathrm{Cl}] \cdot 0.5 \mathrm{CH}_{2} \mathrm{Cl}_{2}$ (2), [ $\left.\mathrm{Au}(\mathrm{meCgPPh}) \mathrm{Cl}\right]$ (3). Figure S13: Fingerprints for $\mathrm{Cl} \ldots \mathrm{H}(17.6 \%$, top) and N .. H (5.2\%, bottom) and Hirshfeld surfaces with those features marked in (2). Figure S14: Fingerprints for $\mathrm{Cl} \ldots \mathrm{H}(18.6 \%$, top) and $\mathrm{O} \ldots \mathrm{H}$ (8.6\%, bottom) and Hirshfeld surfaces with those features marked in (3).

Author Contributions: Conceptualization, M.R.; methodology, M.R., R.M.; software, M.R., M.W., T.M.M.; formal analysis, M.R., R.M., M.W.; investigation, M.R., R.M., M.W., S.B., M.J.C., K.K.-G., J.K.-B., T.M.M.; resources, M.R.; data curation, M.R., R.M.; writing-original draft preparation, M.R.; writing-review and editing, M.R, R.M., T.M.M.; visualization, M.R.; supervision, M.R., R.M.; project administration, M.R.; funding acquisition, M.R. All authors have read and agreed to the published version of the manuscript.

Funding: This research was funded by the Polish National Science Centre (grant no. 2011/03/D/NZ7 /02283).

Institutional Review Board Statement: Not applicable.

Informed Consent Statement: Not applicable.

Data Availability Statement: The data supporting the findings of this study were generated at Collegium Medicum, Nicolaus Copernicus University in Torun. The data are available from the corresponding author (MR) on request.

Acknowledgments: The authors wish to acknowledge the Polish National Science Centre for financial support grants no. 2011/03/D/NZ7/02283.

Conflicts of Interest: The authors declare no conflict of interest.

\section{References}

1. Park, S.-H.; Lee, J.H.; Berek, J.S.; Hu, M.C.T. Auranofin displays anticancer activity against ovarian cancer cells through FOXO3 activation independent of p53. Int. J. Oncol. 2014, 45, 1691-1698. [CrossRef]

2. Marzano, C.; Gandin, V.; Folda, A.; Scutari, G.; Bindoli, A.; Rigobello, M.P. Inhibition of thioredoxin reductase by auranofin induces apoptosis in cisplatin-resistant human ovarian cancer cells. Free Radic. Biol. Med. 2007, 42, 872-881. [CrossRef]

3. Gromer, S.; Arscott, L.D.; Williams, C.H., Jr.; Schirmer, R.H.; Becker, K. Human placenta thioredoxin reductase. Isolation of the selenoenzyme, steady state kinetics, and inhibition by therapeutic gold compounds. J. Biol. Chem. 1998, 273, 20096-20101. [CrossRef]

4. Rigobello, M.P.; Bindoli, A. Mitochondrial thioredoxin reductase purification, inhibitor studies, and role in cell signaling. Methods Enzymol. 2010, 474, 109-122.

5. Karlenius, T.C.; Tonissen, K.F. Thioredoxin and Cancer: A Role for Thioredoxin in all States of Tumor Oxygenation. Cancers 2010, 2, 209-232. [CrossRef] 
6. Saccoccia, F.; Angelucci, F.; Boumis, G.; Carotti, D.; Desiato, G.; Miele, A.E.; Bellelli, A. Thioredoxin reductase and its inhibitors. Curr. Protein Pept. Sci. 2014, 15, 621-646. [CrossRef]

7. Wang, X.; Qian, J.; Zhu, P.; Hua, R.; Liu, J.; Hang, J.; Meng, C.; Shan, W.; Miao, J.; Ling, Y. Novel Phenylmethylenecyclohexenone Derivatives as Potent TrxR Inhibitors Display High Antiproliferative Activity and Induce ROS, Apoptosis, and DNA Damage. ChemMedChem 2021, 16, 702-712. [CrossRef]

8. Mohammadi, F.; Soltani, A.; Ghahremanloo, A.; Javid, H.; Hashemy, S.I. The thioredoxin system and cancer therapy: A review. Cancer Chemother. Pharmacol. 2019, 84, 925-935. [CrossRef]

9. Lu, J.; Chew, E.-H.; Holmgren, A. Targeting thioredoxin reductase is a basis for cancer therapy by arsenic trioxide. Proc. Natl. Acad. Sci. USA 2007, 104, 12288. [CrossRef] [PubMed]

10. Powis, G.; Kirkpatrick, D.L. Thioredoxin signaling as a target for cancer therapy. Curr. Opin. Pharmacol. 2007, 7, 392-397. [CrossRef] [PubMed]

11. Butler, L.M.; Zhou, X.; Xu, W.S.; Scher, H.I.; Rifkind, R.A.; Marks, P.A.; Richon, V.M. The histone deacetylase inhibitor SAHA arrests cancer cell growth, up-regulates thioredoxin-binding protein-2, and down-regulates thioredoxin. Proc. Natl. Acad. Sci. USA 2002, 99, 11700-11705. [CrossRef]

12. Rubbiani, R.; Kitanovic, I.; Alborzinia, H.; Can, S.; Kitanovic, A.; Onambele, L.A.; Stefanopoulou, M.; Geldmacher, Y.; Sheldrick, W.S.; Wolber, G.; et al. Benzimidazol-2-ylidene Gold(I) Complexes Are Thioredoxin Reductase Inhibitors with Multiple Antitumor Properties. J. Med. Chem. 2010, 53, 8608-8618. [CrossRef] [PubMed]

13. Hickey, J.L.; Ruhayel, R.A.; Barnard, P.J.; Baker, M.V.; Berners-Price, S.J.; Filipovska, A. Mitochondria-targeted chemotherapeutics: The rational design of gold(I) N-heterocyclic carbene complexes that are selectively toxic to cancer cells and target protein selenols in preference to thiols. J. Am. Chem. Soc. 2008, 130, 12570-12571. [CrossRef]

14. Kaps, L.; Biersack, B.; Müller-Bunz, H.; Mahal, K.; Münzner, J.; Tacke, M.; Mueller, T.; Schobert, R. Gold(I)-NHC complexes of antitumoral diarylimidazoles: Structures, cellular uptake routes and anticancer activities. J. Inorg. Biochem. 2012, 106, 52-58. [CrossRef]

15. Gandin, V.; Fernandes, A.P.; Rigobello, M.P.; Dani, B.; Sorrentino, F.; Tisato, F.; Björnstedt, M.; Bindoli, A.; Sturaro, A.; Rella, R.; et al. Cancer cell death induced by phosphine gold(I) compounds targeting thioredoxin reductase. Biochem. Pharmacol. 2010, 79, 90-101. [CrossRef]

16. Parrilha, G.L.; Ferraz, K.S.O.; Lessa, J.A.; de Oliveira, K.N.; Rodrigues, B.L.; Ramos, J.P.; Souza-Fagundes, E.M.; Ott, I.; Beraldo, H. Metal complexes with 2-acetylpyridine-N(4)-orthochlorophenylthiosemicarbazone: Cytotoxicity and effect on the enzymatic activity of thioredoxin reductase and glutathione reductase. Eur. J. Med. Chem. 2014, 84, 537-544. [CrossRef]

17. Abbehausen, C.; Peterson, E.J.; de Paiva, R.E.F.; Corbi, P.P.; Formiga, A.L.B.; Qu, Y.; Farrell, N.P. Gold(I)-Phosphine-N-Heterocycles: Biological Activity and Specific (Ligand) Interactions on the C-Terminal HIVNCp7 Zinc Finger. Inorg. Chem. 2013, 52, 11280-11287. [CrossRef] [PubMed]

18. Yeo, C.I.; Ooi, K.K.; Tiekink, E.R.T. Gold-Based Medicine: A Paradigm Shift in Anti-Cancer Therapy? Molecules 2018, 23, 1410. [CrossRef]

19. Marzo, T.; Cirri, D.; Gabbiani, C.; Gamberi, T.; Magherini, F.; Pratesi, A.; Guerri, A.; Biver, T.; Binacchi, F.; Stefanini, M.; et al. Auranofin, Et(3)PAuCl, and Et(3)PAuI Are Highly Cytotoxic on Colorectal Cancer Cells: A Chemical and Biological Study. ACS Med. Chem. Lett. 2017, 8, 997-1001. [CrossRef]

20. De Nisi, A.; Bergamini, C.; Leonzio, M.; Sartor, G.; Fato, R.; Naldi, M.; Monari, M.; Calonghi, N.; Bandini, M. Synthesis, cytotoxicity and anti-cancer activity of new alkynyl-gold(i) complexes. Dalton Trans. 2016, 45, 1546-1553. [CrossRef]

21. Zou, T.; Lum, C.T.; Lok, C.-N.; Zhang, J.-J.; Che, C.-M. Chemical biology of anticancer gold(III) and gold(I) complexes. Chem. Soc. Rev. 2015, 44, 8786-8801. [CrossRef]

22. Maggini, S. Classification of P,N-binucleating ligands for hetero- and homobimetallic complexes. Coord. Chem. Rev. 2009, 253, 1793-1832. [CrossRef]

23. Munzeiwa, W.A.; Omondi, B.; Nyamori, V.O. Architecture and synthesis of P,N-heterocyclic phosphine ligands. Beilstein J. Org. Chem. 2020, 16, 362-383. [CrossRef]

24. Berners-Price, S.J.; Sadler, P.J. Phosphines and Metal Phosphine Complexes: Relationship of Chemistry to Anticancer and Other Biological Activity. In Bioinorganic Chemistry; Springer: Berlin/Heidelberg, Germany, 1988; pp. 27-102.

25. Murray, B.S.; Babak, M.V.; Hartinger, C.G.; Dyson, P.J. The development of RAPTA compounds for the treatment of tumors. Coord. Chem. Rev. 2016, 306, 86-114. [CrossRef]

26. Phillips, A.D.; Gonsalvi, L.; Romerosa, A.; Vizza, F.; Peruzzini, M. Coordination chemistry of 1,3,5-triaza-7-phosphaadamantane (PTA): Transition metal complexes and related catalytic, medicinal and photoluminescent applications. Coord. Chem. Rev. 2004, 248, 955-993. [CrossRef]

27. Bravo, J.; Bolaño, S.; Gonsalvi, L.; Peruzzini, M. Coordination chemistry of 1,3,5-triaza-7-phosphaadamantane (PTA) and derivatives. Part II. The quest for tailored ligands, complexes and related applications. Coord. Chem. Rev. 2010, $254,555-607$. [CrossRef]

28. Miranda, S.; Vergara, E.; Mohr, F.; de Vos, D.; Cerrada, E.; Mendía, A.; Laguna, M. Synthesis, Characterization, and in Vitro Cytotoxicity of Some Gold(I) and Trans Platinum(II) Thionate Complexes Containing Water-Soluble PTA and DAPTA Ligands. X-ray Crystal Structures of [Au(SC4H3N2)(PTA)], trans-[Pt(SC4H3N2)2(PTA)2], trans-[Pt(SC5H4N)2(PTA)2], and trans[Pt(SC5H4N)2(DAPTA)2]. Inorg. Chem. 2008, 47, 5641-5648. [PubMed] 
29. Rotta-Loria, N.L.; Chisholm, A.J.; MacQueen, P.M.; McDonald, R.; Ferguson, M.J.; Stradiotto, M. Exploring the Influence of Phosphine Ligation on the Gold-Catalyzed Hydrohydrazination of Terminal Alkynes at Room Temperature. Organometallics 2017, 36, 2470-2475. [CrossRef]

30. Bats, J.W.; Hamzic, M.; Hashmi, A.S. RefCODE:GASLUK, CCDC 1538193: Experimental Crystal Structure Determination. 2017. Available online: https:/ /www.research.manchester.ac.uk/portal/en/datasets/ccdc-1429470-experimental-crystal-structuredetermination(b59b2c1f-b73c-486e-bfc7-53c2107344ef).html (accessed on 18 November 2021).

31. Mann, F.G.; Wells, A.F.; Purdie, D. The constitution of complex metallic salts. Part VI. The constitution of the phosphine and arsine derivatives of silver and aurous halides. The configuration of the co-ordinated argentous and aurous complex. J. Chem. Soc. 1937, 1828-1836. [CrossRef]

32. Oxford Diffraction. CrysAlis RED and CrysAlis CCD; Oxford Diffraction Ltd.: Abingdon, UK, 2006. Available online: https: / /journals.iucr.org/e/services/stdswrefs.html (accessed on 1 October 2021).

33. Sheldrick, G.M. SHELXS97, SHELXL97 and CIFTAB; University of Göttingen Germany: Göttingen, Germany, 1997.

34. Sheldrick, G. Crystal structure refinement with SHELXL. Acta Crystallogr. Sect. C 2015, 71, 3-8. [CrossRef]

35. Brandenburg, K.D. Release 2.1e; Crystal Impact GbR: Bonn, Germany, 2001.

36. Farrugia, L. ORTEP-3 for Windows-A version of ORTEP-III with a Graphical User Interface (GUI). J. Appl. Crystallogr. 1997, 30 Pt 1, 565. [CrossRef]

37. Richert, M.; Walczyk, M.; Cieślak, M.J.; Kaźmierczak-Barańska, J.; Królewska-Golińska, K.; Wrzeszcz, G.; Muzioł, T.; Biniak, S. Synthesis, X-ray structure, physicochemical properties and anticancer activity of mer and fac Ru(iii) triphenylphosphine complexes with a benzothiazole derivative as a co-ligand. Dalton Trans. 2019, 48, 10689-10702. [CrossRef]

38. Singer, R.A.; Doré, M.; Sieser, J.E.; Berliner, M.A. Development of nonproprietary phosphine ligands for the Pd-catalyzed amination reaction. Tetrahedron Lett. 2006, 47, 3727-3731. [CrossRef]

39. Singer, R.A.; Caron, S.; McDermott, R.E.; Arpin, P.; Do, N.M. Alternative Biarylphosphines for Use in the Palladium-Catalyzed Amination of Aryl Halides. Synthesis 2003, 2003, 1727-1731. [CrossRef]

40. Singer, R.A. BippyPhos: A Highly Versatile Ligand for Pd-Catalyzed C-N, C-O and C-C Couplings. Isr. J. Chem. 2020, 60, 294-302. [CrossRef]

41. Crawford, S.M.; Lavery, C.B.; Stradiotto, M. BippyPhos: A Single Ligand With Unprecedented Scope in the Buchwald-Hartwig Amination of (Hetero)aryl Chlorides. Chem. A Eur. J. 2013, 19, 16760-16771. [CrossRef] [PubMed]

42. Adjabeng, G.; Brenstrum, T.; Frampton, C.S.; Robertson, A.J.; Hillhouse, J.; McNulty, J.; Capretta, A. Palladium Complexes of 1,3,5,7-Tetramethyl-2,4,8-trioxa-6-phenyl-6-phosphaadamantane: Synthesis, Crystal Structure and Use in the Suzuki and Sonogashira Reactions and the $\alpha$-Arylation of Ketones. J. Org. Chem. 2004, 69, 5082-5086. [CrossRef] [PubMed]

43. Alvino, J.F.; Bennett, T.; Anderson, D.; Donoeva, B.; Ovoshchnikov, D.; Adnan, R.H.; Appadoo, D.; Golovko, V.; Andersson, G.; Metha, G.F. Far-infrared absorption spectra of synthetically-prepared, ligated metal clusters with Au6, Au8, Au9 and Au6Pd metal cores. RSC Adv. 2013, 3, 22140-22149. [CrossRef]

44. Coates, J. Interpretation of Infrared Spectra, A Practical Approach. In Encyclopedia of Analytical Chemistry; Wiley: Hoboken, NJ, USA, 2006.

45. Schwarz, C.; Handelmann, J.; Baier, D.M.; Ouissa, A.; Gessner, V.H. Mono- and diylide-substituted phosphines (YPhos): Impact of the ligand properties on the catalytic activity in gold(i)-catalysed hydroaminations. Catal. Sci. Technol. 2019, 9, 6808-6815. [CrossRef]

46. Hu, X.-Q.; Lichte, D.; Rodstein, I.; Weber, P.; Seitz, A.-K.; Scherpf, T.; Gessner, V.H.; Gooßen, L.J. Ylide-Functionalized Phosphine (YPhos)-Palladium Catalysts: Selective Monoarylation of Alkyl Ketones with Aryl Chlorides. Org. Lett. 2019, 21, 7558-7562. [CrossRef]

47. Zuccarello, G.; Mayans, J.G.; Escofet, I.; Scharnagel, D.; Kirillova, M.S.; Pérez-Jimeno, A.H.; Calleja, P.; Boothe, J.R.; Echavarren, A.M. Enantioselective Folding of Enynes by Gold(I) Catalysts with a Remote C2-Chiral Element. J. Am. Chem. Soc. 2019, 141, 11858-11863. [CrossRef]

48. Hartlaub, S.F.; Lauricella, N.K.; Ryczek, C.N.; Furneaux, A.G.; Melton, J.D.; Piro, N.A.; Kassel, W.S.; Nataro, C. Late Transition Metal Compounds with 1,1'-Bis(phosphino)ferrocene Ligands. Eur. J. Inorg. Chem. 2017, 424-432. [CrossRef]

49. Homs, A.; Escofet, I.; Echavarren, A.M. On the Silver Effect and the Formation of Chloride-Bridged Digold Complexes. Org. Lett. 2013, 15, 5782-5785. [CrossRef] [PubMed]

50. Zhu, Y.; Day, C.S.; Zhang, L.; Hauser, K.J.; Jones, A.C. A Unique Au-Ag-Au Triangular Motif in a Trimetallic Halonium Dication: Silver Incorporation in a Gold(I) Catalyst. Chem. A Eur. J. 2013, 19, 12264-12271. [CrossRef]

51. Hu, J.-Y.; Zhang, J.; Wang, G.-X.; Sun, H.-L.; Zhang, J.-L. Constructing a Catalytic Cycle for C-F to C-X (X = O, S, N) Bond Transformation Based on Gold-Mediated Ligand Nucleophilic Attack. Inorg. Chem. 2016, 55, 2274-2283. [CrossRef]

52. Hill, D.T. a. S. B.M. (2,3,4,6-Tetra-O-acetyl-1-thio- $\beta$-D-glucopyranosato-S) (triethylphosphine)gold. Cryst. Struct. Commun. 1980, 9, 679-686.

53. Spackman, M.A.; Jayatilaka, D. Hirshfeld surface analysis. CrystEngComm 2009, 11, 19-32. [CrossRef]

54. Spackman, M.A.; McKinnon, J.J. Fingerprinting intermolecular interactions in molecular crystals. CrystEngComm 2002, 4, 378-392. [CrossRef]

55. Kariuki, B.M.; Newman, P.D. Asymmetric Cationic Phosphines: Synthesis, Coordination Chemistry, and Reactivity. Inorg. Chem. 2018, 57, 9554-9563. [CrossRef] 
56. Cunningham, T.J.; Elsegood, M.R.J.; Kelly, P.F.; Smith, M.B.; Staniland, P.M. Coordination Studies of a New Nonsymmetric Ditertiary Phosphane Bearing a Single Phosphaadamantane Cage. Eur. J. Inorg. Chem. 2008, 2326-2335. [CrossRef]

57. Kim, J.H.; Reeder, E.; Parkin, S.; Awuah, S.G. Gold(I/III)-Phosphine Complexes as Potent Antiproliferative Agents. Sci. Rep. 2019, 9, 12335. [CrossRef] [PubMed]

58. Leeson, P.D.; Springthorpe, B. The influence of drug-like concepts on decision-making in medicinal chemistry. Nat. Rev. Drug Discov. 2007, 6, 881-890. [CrossRef] [PubMed]

59. Waring, M.J. Lipophilicity in drug discovery. Expert Opin. Drug Discov. 2010, 5, 235-248. [CrossRef]

60. Hopkins, A.L.; Keserü, G.M.; Leeson, P.D.; Rees, D.C.; Reynolds, C.H. The role of ligand efficiency metrics in drug discovery. Nat. Rev. Drug Discov. 2014, 13, 105-121. [CrossRef]

61. Chmiel, T.; Mieszkowska, A.; Kempińska-Kupczyk, D.; Kot-Wasik, A.; Namieśnik, J.; Mazerska, Z. The impact of lipophilicity on environmental processes, drug delivery and bioavailability of food components. Microchem. J. 2019, 146, 393-406. [CrossRef]

62. Gabathuler, R. Approaches to transport therapeutic drugs across the blood-brain barrier to treat brain diseases. Neurobiol. Dis. 2010, 37, 48-57. [CrossRef]

63. Deo, K.M.; Sakoff, J.; Gilbert, J.; Zhang, Y.; Aldrich Wright, J.R. Synthesis, characterisation and influence of lipophilicity on cellular accumulation and cytotoxicity of unconventional platinum(iv) prodrugs as potent anticancer agents. Dalton Trans. 2019, 48, 17228-17240. [CrossRef] [PubMed]

64. Landini, I.; Lapucci, A.; Pratesi, A.; Massai, L.; Napoli, C.; Perrone, G.; Pinzani, P.; Messori, L.; Mini, E.; Nobili, S. Selection and characterization of a human ovarian cancer cell line resistant to auranofin. Oncotarget 2017, 8, 96062-96078. [CrossRef]

65. Shaw, C.F. Gold-Based Therapeutic Agents. Chem. Rev. 1999, 99, 2589-2600. [CrossRef]

66. Coffer, M.T.; Shaw, C.F.; Eidsness, M.K.; Watkins, J.W.; Elder, R.C. Reactions of auranofin and chloro(triethylphosphine)gold with bovine serum albumin. Inorg. Chem. 1986, 25, 333-339. [CrossRef]

67. Coffer, M.T.; Shaw, C.F.; Hormann, A.L.; Mirabelli, C.K.; Crooke, S.T. Thiol competition for Et3PAuS-albumin: A nonenzymatic mechanism for Et3PO formation. J. Inorg. Biochem. 1987, 30, 177-187. [CrossRef]

68. Schmidt, C.; Albrecht, L.; Balasupramaniam, S.; Misgeld, R.; Karge, B.; Brönstrup, M.; Prokop, A.; Baumann, K.; Reichl, S.; Ott, I. A gold(i) biscarbene complex with improved activity as a TrxR inhibitor and cytotoxic drug: Comparative studies with different gold metallodrugs. Metallomics 2019, 11, 533-545. [CrossRef] [PubMed]

69. Tolbatov, I.; Cirri, D.; Marchetti, L.; Marrone, A.; Coletti, C.; Re, N.; La Mendola, D.; Messori, L.; Marzo, T.; Gabbiani, C.; et al. Mechanistic Insights Into the Anticancer Properties of the Auranofin Analog Au(PEt3)I: A Theoretical and Experimental Study. Front. Chem. 2020, 8. [CrossRef] [PubMed] 